Business group heterogeneity and the internationalization-performance relationship: Evidence from Indian business groups

\author{
Saptarshi Purkayastha \\ Assistant Professor \\ Department of Strategic Management \\ Indian Institute of Management Calcutta \\ India \\ saptarshi@iimcal.ac.in \\ Vikas Kumar $^{\mathrm{a}}$ \\ Associate Professor, Discipline of International Business \\ University of Sydney Business School \\ Sydney, Australia \\ vikas.kumar@sydney.edu.au \\ Ph: +61293516438 \\ Jane Wenzhen Lu \\ James Riady Chair in Asian Business and Economics \\ Department of Management \& Marketing \\ The University of Melbourne \\ Melbourne, Australia \\ jane.lu@unimelb.edu.au
}

a. Corresponding author 


\title{
Business group ownership heterogeneity and the internationalization-performance relationship: Evidence from Indian business groups
}

\author{
Abstract \\ Business groups, the dominant organizational form in many Asian markets, have expanded \\ their operations into international markets. We combine the resource-based view with the \\ institutional perspective to highlight the costs and benefits of business groups' \\ internationalization, rather than business groups' affiliated firms' internationalization, and \\ consider how ownership heterogeneity among business groups influences the \\ internationalization-performance relationship. Three ownership types-family, domestic \\ financial institution, and foreign corporate — serve as distinguishing characteristics of \\ business groups and potential moderators of this relationship. In a sample of 185 Indian \\ business groups examined over more than a decade (2000-2010), we find that these three \\ ownership types have a differential impact on the internationalization-performance \\ relationship, depending on the level of internationalization of the business group. \\ Specifically, we find that at lower levels of internationalization, family and foreign corporate \\ ownership has a positive moderating effect whereas domestic financial institutional \\ ownership has a negative moderating effect. Conversely ${ }_{s}$ at higher levels of \\ internationalization, family and foreign corporate ownership has a negative moderating \\ effect, while domestic financial institutional ownership positively moderates the \\ internationalization-performance relationship.
}

Keywords: Business groups, ownership heterogeneity, internationalization, business group performance 


\section{Introduction}

Knowledge about business groups (Carney, Gedajlovic, Heugens, Essen, \& Oosterhout, 2011; Chen, Chittoor, \& Vissa, 2015; Ayyagari, Dau, \& Spencer, 2015) and emerging market multinationals (Cuervo-Cazurra, 2012; Ramamurti \& Singh, 2009) has significantly improved in the past decade, but research at the interface of these two phenomena is conspicuously absent. This paucity of research in this area is surprising, given the important role that business groups play in the socio-economic landscape of emerging markets (Khanna \& Yafeh, 2007) and the rapid pace with which emerging market multinationals are internationalizing (Guillén \& Garcia-Canal, 2012; Luo \& Tung, 2007; Mathews, 2006) and becoming globally competitive entities (Kumar, Mudambi \& Gray, 2013). In an attempt to advance our knowledge in this area, we focus on internationalization-performance relationship at the business group level.

Business groups are networks of legally independent firms, bound together by formal and informal ties (Khanna \& Rivkin, 2001; Zattoni, Pedersen, \& Kumar, 2009), with a central unit that is responsible for coordinating among the affiliate firms (Leff, 1978). This coordination is manifest in key strategic decisions, such as those related to internationalization and resource sharing, made at the group instead of the affiliate firm level (Chang \& Hong, 2000; Kumar, Gaur, \& Pattnaik, 2012). Our underlying premise is that strategically important decisions, such as those pertaining to internationalization, take place at the group level rather than the affiliate firm level.

Studies of business groups usually adopt an institutional perspective, suggesting that the groups originate in response to prevalent institutional voids (Chang \& Hong, 2000; Guillén, 2000; Khanna \& Palepu, 1997, 2000). In turn, they address the performance 
consequences of business group affiliation, mostly in domestic contexts (Chacar \& Vissa, 2005; Chang, Chung, \& Mahmood, 2006; Douma, George, \& Kabir, 2006; Khanna \& Rivkin, 2001; Zattoni et al., 2009). The few studies that examine the internationalizationperformance relationship of business group affiliated firms show mixed and often conflicting findings (negative impacts in Chittoor, Sarkar, Ray, \& Aulakh, 2009; Gaur \& Kumar, 2009; Hundley \& Jacobsen, 1998; positive impacts in Chang, 1995; Elango \& Pattnaik, 2007; Lamin, 2013).

Although some of the theoretical arguments pertaining to the internationalizationperformance relationship at the firm level might be applicable at the group level, the contextual differences between groups and firms - arising primarily from the scope of their presence in multiple industries and control over resource allocation (Gubbi, Aulakh, \& Ray, 2015) — suggest the need to investigate this relationship uniquely at the business group level. For example, with their unique attributes allowing for greater financial and network resources compared to individual firms (Yiu, 2011), business groups can relatively easily overcome the liabilities of foreignness and newness (Lamin, 2013), yet their greater diversity likely increases their control and coordination costs (Kumar et al., 2012; Ramaswamy, Li, \& Petitt, 2012). Both product and international diversifications require resources; if a business group is diverse in both fields, it has fewer resources available to support each of these strategies (Kumar et al., 2012). A combination of the above factors leads to the prediction that the relationship between internationalization and performance is nonlinear (see Contractor, Kundu \& Hsu, 2003; Gaur \& Kumar, 2009; Lu \& Beamish, 2004; Ruigrok \& Wagner, 2003).

More importantly, we anticipate that more nuanced effects may emerge from an investigation of the moderators of this internationalization-performance relationship (Kirca, Roth, Hult, \& Cavusgil, 2012; Li, 2007; Rugman \& Oh; 2010; Verbeke \& Forootan, 2012). 
Previous studies have examined the effect of ownership structure on diversification, both internationally and domestically (Bhaumik, Driffield, \& Pal, 2010; Gaur \& Delios, 2015; Ramaswamy, Li, \& Veliyath, 2002); and the effect of ownership types (e.g., state, foreign, domestic) on innovation in the context of China (Chen, Li, Shapiro, \& Zhang, 2014) and on international diversification in the context of United States (Tihanyi, Johnson, Hoskission, \& Hitt, 2003). We add to this discussion by investigating the moderating effects of ownership by three specific types of owners - family, domestic financial institution, and foreign corporate — on the internationalization-performance relationship of business groups in India. Our study makes a couple of important contributions to extant literature. First, rather than studying the internationalization-performance relationship at the firm level (Kirca et al., 2012; Yaprak \& Karademir, 2010) or infer group effects from affiliate-level firm data (e.g., Chittoor \& Ray 2007; Gaur \& Kumar, 2009; Singh \& Gaur, 2013), we establish conceptual and empirical evidence of the relationship between group level internationalization and group level profitability. With a few exceptions (Ghemawat \& Khanna, 1998; Kumar et al., 2012; Tan \& Meyer, 2010), prior research does not explicitly equilibrate the construct and the measurement levels, thereby creating disconnect between theoretical approaches that investigate group-level processes; and empirical research that examines those processes using affiliate-level firm data (Carney et al., 2011). To address this concern, we examine both internationalization and performance at the group level. This alignment should provide a more accurate estimate of the performance implications of an international strategy.

Second, we include group heterogeneity, in the form of the degree of ownership by specific owners, and its effects on the internationalization - performance relationship. That is, different types of owners with different degrees of ownership exert unique moderating effects on this relationship, and this effect also varies as business groups move from lower to higher 
levels of internationalization. Using a sample of 185 business groups over a period of 20002010,we find that at lower levels of internationalization, family and foreign corporate ownership has a positive moderating effect whereas domestic financial institutional ownership has a negative moderating effect. Conversely, at higher levels of internationalization, family and foreign corporate ownership has a negative moderating effect, while domestic financial institutional ownership positively moderates the internationalization-performance relationship. The varying motives of different owners and their changing effects at different levels of internationalization reinforce the notion that to understand the performance consequences of internationalization, we must consider not only ownership concentration levels but also the owners' identities (Chen et al., 2014; Ramaswamy et al., 2002).

\section{Theoretical Background}

Internationalization-performance relationship

International business literature is replete with studies that suggest various shapes for the relationship between internationalization and firm performance (Bausch \& Krist, 2007; Contractor et al., 2003; Kirca et al., 2012; Lu \& Beamish, 2001, 2004; Oh \& Contractor, 2012; 2014; Thomas \& Eden, 2004), which may imply problems with the empirical nature (Verbeke, Li, \& Goerzen, 2009; Verbeke \& Forootan, 2012) or theoretical rationale (Hennart, 2007) utilized in these studies. Potential explanations of the contrasting results suggest various moderating effects, as Table 1 summarizes. Internationalization-performance research has advanced our understanding of the focal relationship through incorporation of a 
number of moderating factors such as internationalization motivations, entry mode, institutional distance, resources, business group affiliation, regional expansion, type of multinationality and the like (see Chang \& Rhee 2011; Chao \& Kumar 2010; Gaur \& Kumar 2009; Kirca et al., 2012; Oh \& Contractor, 2012; 2014; Rugman \& Oh, 2010; Verbeke et al., 2009). We seek to extend this stream of literature by examining the moderating effect of business group heterogeneity, in the form of degree of ownership by specific owners, on the internationalization - performance relationship.

--Please insert Table 1 about here--

We argue that the internationalization-performance relationship reflects the combined effects of the costs and benefits of internationalization, as firms progress from one stage to the next in their internationalization journey (Contractor et al., 2003; Lu \& Beamish, 2004). Internationalization costs arise from liabilities of foreignness and newness (Hymer, 1976; Zaheer, 1995), which decrease with greater experience in the host country (Barkema, Bell, \& Pennings, 1996) but are never completely eradicated (Lu \& Beamish, 2004). These liabilities become manifest in the challenges foreign firms face in purchasing and installing facilities, staffing, and establishing internal management systems and external business networks (Lu \& Beamish, 2004). Therefore, transaction costs increase, as do information costs in unfamiliar institutional contexts (Chao \& Kumar, 2010). Such challenges might adversely affect firm performance more at the lower stages of internationalization. The effects of these costs may be more acute on the performance of emerging economy firms which tend to be small (Contractor, Kumar \& Kundu, 2007; Gaur \& Kumar, 2009) thereby having lesser resources to overcome them. Coming from weaker institutional contexts, availability of such resources in the open market are also scarce (Hitt, Connelly, Tihanyi, \& Certo, 2010). However, internationalization also provides benefits due to economies of scale and scope (Contractor, 
2012), risk diversification (Kim, Hwang, \& Burgers, 1993), increased market power (Kogut, 1985), an ability to exploit market imperfections through intangible firm-specific assets (Caves, 1971), experiential learning (Barkema \& Vermeulen, 1998), and the location-specific advantages of functioning in different country markets (Kogut \& Chang, 1991).

Just as firms do, business groups should experience these costs and benefits, though with some adjustments. For example, business groups are larger than individual firms, so they can absorb more operational and commercial risks in international ventures (Fiegenbaum, Shaver \& Yeung, 1997; George \& Kabir, 2012). They thus might get the benefits of internationalization, such as economies of scale and scope, earlier than individual firms do (e.g., before the growth stage; Contractor et al., 2007). They can also overcome the challenges and costs of liabilities of foreignness and newness by leveraging network resources to acquire knowledge about the new market and avoid common mistakes usually made by new entrants (Manikandan \& Ramachandran, 2015). Stakeholders in foreign markets (e.g., customers, suppliers, employees, investors) tend to feel more comfortable interacting with business groups, whose size seemingly reflects their greater reliability and ability to conduct business. Such reputation-enhancing effects facilitate legitimacy building in the host market, which help reduce the costs associated with overcoming the liabilities of foreignness and newness. Morck, Wolfenzon, and Yeung (2005) argue that business groups benefit from a reputation for fair dealing with business partners; Khanna and Palepu (2000) reason that reputation effects provide business groups superior access to foreign capital and technological resources. With their greater political power (Carney, 2004; Claessens, Djankov, \& Lang, 2000; Dieleman \& Sachs, 2008), business groups can procure the necessary approvals from the government for quick market entry (Khanna \& Yafeh, 2007; Mackie, 1992; Yoshihara, 1988), which in turn restricts the costs associated with 
internationalization. In short, compared to an unaffiliated firm, it is easier for a business group to amortize the costs of internationalization at lower levels over a larger base, which reduces the negative potential effects on the business group's performance. Greater resources in the form of technological and market knowledge available to the business group will enhance absorptive capacities (Lichtenthaler, 2009), which should allow business groups to assimilate new knowledge and reduce their costs for subsequent international expansion. Therefore, the net impact of internationalization by business groups on performance should be positive at lower levels of internationalization.

As business groups progress to higher levels of internationalization, they face newer challenges that dampen their overall performance. Unlike individual firms, business groups tend to be deeply embedded in the institutional fabric of their domestic market (Pedersen \& Stucchi, 2014; Zattoni et al., 2009), so learning about a large number of foreign markets can be difficult. To reduce inefficiencies in their home markets, business groups often create internal capital, labor, and product markets so they can circumvent institutional voids and reduce transaction costs (Khanna \& Palepu, 1997; Khanna \& Rivkin, 2001; Wan \& Hoskisson, 2003). But these strategies will not be as effective in international operations, particularly in developed markets, where these intermediary institutions may already be present. The value of internalizing such operations may, thus, diminish, particularly at higher levels of internationalization and when the groups enter relatively more developed institutional markets (Gaur \& Kumar, 2009). Instead, coordination and control costs become magnified for business groups, which already have high levels of product diversification, but now need to govern units in disparate geographies because of increased internationalization. Operating simultaneously in multiple industries and countries lead groups to overstretch their resources, resulting in suboptimal decisions and reduced performance (Kumar et al., 2012). 
India ${ }_{s}$ compared to other emerging markets, serves as home base of many business groups (Khanna \& Palepu 2000 ). Some of these business groups such as Tatas, have a high level of internationalization (almost two-third of Tata's revenue come from international markets) while there are others that are at much lower levels of internationalization. Accordingly, we predict that different levels of internationalization would have different impact on performance. In other words, at lower levels, internationalization increases performance; however, at higher levels s internationalization decreases performance.

Hypothesis 1a: Internationalization has a positive effect on performance for Indian business groups at lower levels of internationalization.

Hypothesis $1 \mathrm{~b}$ : Internationalization has a negative effect on performance for Indian business groups at higher levels of internationalization.

Ownership and internationalization

Research into ownership and internationalization (Gaur \& Delios, 2015; Yaprak \& Karademir, 2010) generally concentrates on "different ownership structures—concentrated or dispersed - and not on the types of owners ... despite its predictable implications" (Fernández \& Nieto, 2006: 340). Ownership types differ in their expectations and intensity of monitoring (Monks \& Minow, 1995). Some owners become active only after acquiring sizeable equity holdings; others may engage in active monitoring even at lower ownership levels (Brickley, Lease, \& Smith, 1988). In India, domestic financial shareholders of business groups are usually government organizations with limited involvement on the groups' strategic decisions; whereas foreign corporate shareholders with minority shareholdings are often vocal in internationalization decisions (Aguilera \& Jackson, 2003). As Ramaswamy et al. (2002: 348) point out, "who owns might be just as important as how much they own." 
Chen et al. (2014) show that diversity in ownership types is more important than ownership concentration for explaining the innovation performance of Chinese listed companies. Tihanyi et al. (2003) demonstrate a positive relationship between institutional owners in the United States (professional investment funds and pension funds) and the level of international diversification. Manikandan and Ramachandran (2015) argue that the presence of an external governance mechanism in the form of a separate board lends a multi-entity character to business group firms, enabling greater growth opportunities. We elaborate on the context of India to argue that varying degrees of three particular ownership types_-family, domestic financial institution, and foreign corporate - moderate the internationalization-performance relationship differently.

Degree of family ownership. Family dominance defines business groups in India. Family ownership confers competitive advantages on groups, including a long-term orientation (Allen \& Phillips, 2000), flexibility (Poza, Alfred \& Maheshwari, 1997), speedy decision making (Zahra, 2003), and the family name as a source of power and pride (Bhaumik et al., 2010). Founding families maintain a dedicated presence in firms affiliated to their business groups, with longer time horizons than most other owners, such that they are willing to invest in projects that require longer durations to complete (Anderson \& Reeb, 2003). The following quote (Economic Times, 2014) about Reliance, one of the biggest family owned business groups, is suggestive of the long term nature of family involvement in affiliated firms:

“..Mukesh Ambani's twins, son Akash and daughter Isha, were inducted into the boards of Reliance Retail and Reliance Jio Infocomm last year. The next natural step would be to graduate them to Reliance Industries board. Already, Nita Ambani is there on RIL's board, 
along with the cousins of Mukesh, the Meswanis, from the family. The ownership position of the family is also safer as they control 45.25 per cent stake in the company. So, transferring control will not be a worry."

Internationalization, especially in initial stages, requires significant investments (Contractor et al., 2007) and a long-term view of the international operation. Casson (1999) and Chami (1999) show that families regard their business groups as an asset to pass on to descendants, rather than as wealth to consume during their lifetimes, so they are likely to support international expansion strategies that appear promising for competitive advantages in the longer term.

Family members also are insiders (Kim et al., 2008), enjoying privileged access to proprietary company information. In emerging economies, controlling families enjoy substantial power (Claessens et al., 2000). Ownership structures involving crossholding or control pyramids, coupled with informal axes of power and influence, allow family owners to wield much more control than their equity stake might suggest (Bhaumik et al., 2010; Claessens et al., 2000). Thus, family members can resist pressures from other owners or management and often exert pressure on other groups of owners (Johnson, Schnatterly, Johnson, \& Chiu, 2010) in strategic decisions, particularly with respect to resource allocations (Kim et al., 2008). At lower levels of internationalization, such resources are the most critical, because they help alleviate the pressures and costs imposed by liabilities of foreignness and newness. In this sense, a higher degree of family ownership should allow business groups to expand into international markets more profitably.

However, as family-owned business groups increase their internationalization, these advantages may fade. Habbershon and Williams (1999) argue that generic advantages of a high degree of family ownership are misleading in internationalization contexts, because 
family-dominated groups tend to be risk averse as the investments in the businesses are mainly the owners' own wealth (Clavier, Rienda, \& Quer, 2009). Therefore, groups avoid making riskier international investments, especially in intangible, knowledge-based assets such as technologies, brands, or qualified personnel (Nieto, 2001) that can lead to greater profitability gains through growth (Lu \& Beamish, 2004). Without resource commitments to create knowledge-based assets, the benefits of increased scale and scope at higher levels of internationalization get suppressed. Similarly, centralized decision-making norms in family dominated business groups often lead to informal channels of communication, ambiguous lines of authority, and poor organizational systems. These factors enable groups to respond quickly, but they may stymie international expansion, which demands complex, decentralized structures and formal control (Daily \& Dollinger, 1993; Fernandez \& Nieto, 2006). At higher levels of internationalization, coordination and control mechanisms become inefficient due to the increasing complexity, prompting higher than average governance costs. Group owners might treat organizations as "personal fiefdoms" (Majocchi \& Strange, 2012) and regard decentralizing as a loss of personal control (Ward, 1988). Such an approach quickly becomes unsustainable as the firm progresses in its international pursuits, imposing costs due to inefficient control mechanisms.

Finally, business groups with a high degree of family ownership may be reluctant to internationalize when faced with the challenges of transferring business models rooted in the home culture to new cultural and institutional contexts (Gallo \& Sveen, 1991). If familyowned groups have depended on family ties for hiring decisions, they might lack the internal skills required for international ventures (Zahra, 2003). If success in international markets requires the delegation of decision-making power to outside professionals, family members may recoil, especially if their domestic emerging market contexts are characterized by weak 
property rights and rely on informal contracts. Thus, from a resource-based perspective, families lack the necessary resources to manage the internationalization of their business groups, particularly at high levels. Internationalization may also subject the business groups to external scrutiny from host country regulators and investors (Bhaumik et al., 2010). Such scrutiny, which increases with greater internationalization, could highlight the common practice among business groups of (mis-) appropriating funds from minority shareholders through tunneling (Baek, Kang, \& Lee, 2006; Bertrand, Mehta, \& Mullainathan, 2002), which often goes unpunished in emerging markets that lack strict corporate governance rules or organizational transparency. The positive moderating effect of degree of family ownership at lower levels of internationalization thus may be overshadowed by negative effects due to coordination and control issues at higher levels. In sum, once a high level of internationalization is reached, the expansive international operation adds significant complication to the diversified domestic structure in terms of severe coordination and control issues. This is when the risk-averse nature of family firms start to have a visible negative moderating effect on the performance since the traditional safe foreign markets may have already been served and only riskier locations left. These forces lead to an overall negative moderating effect at higher levels of internationalization.

Hypothesis 2a: Family ownership, in Indian business groups, has a positive moderating effect at lower levels of internationalization.

Hypothesis 2b: Family ownership, in Indian business groups, has a negative moderating effect at higher levels of internationalization.

Degree of domestic financial institutional ownership. In India, domestic financial institutions consist mainly of government-owned financial institutions, insurance companies, and banks (Douma et al., 2006). Liberalization led to the partial privatization of some 
institutions, but the market still reflects the vestiges of state ownership (Ramaswamy et al., 2002). Institutions with substantial government ownership generally have relaxed attitude towards monitoring the companies in which they have invested (Ramaswamy et al., 2002). First, government nominees to boards tend to be bureaucrats with minimal international experience and capabilities. Although they provide critical networks for business groups (Ramamurti, 2000), we contend that they might not be effective in facilitating internationalization during the initial stages of the internationalization process. In the complex internationalization processes, especially at the lower levels which are marked by liabilities of foreignness and newness, government-based linkages may create greater inertia rather than encourage business groups to be entrepreneurial and innovative. Governmentbased contacts might help groups leverage location-based advantages, but they are countryspecific and not easily mobile across geographical contexts (Nachum, 2000).

Second, even if the government-affiliated board nominees have international acumen, they lack a strong incentive to engage in effective monitoring, because their career prospects rarely depend on firm profitability. Rather, governments often pursue social welfare objectives and are less profit driven, which implies less vigilant monitoring (Douma et al., 2006; Ramaswamy et al., 2002). From a resource-based perspective, domestic financial institutions lack the resources to help business groups alleviate costs and capitalize on benefits at lower levels of the internationalization. This adversely effects the overall performance of business groups at lower levels of internationalization as costs are typically high and managing them is critical.

Third, business group owners who maintain links with the political elite retain substantial clout over the functioning of these government-owned institutions, such that government agents tend to side with the management preferences of the family (Filatotchev, 
Lien, \& Piesse, 2005). In some instances this attribute might encourage internationalization, by supporting risk-taking behavior, but it does not help reduce internationalization costs or improve the benefits.

Fourth, domestic financial institutions often link commercially with business groups, so their earnings depend on interest income earned from loans or various fees charged to meet the business groups' financial needs. This dependence creates a delicate position, so they cannot effectively monitor or control group activities. Despite their substantial holdings, domestic financial institutions thus might be reluctant to advise groups against specific internationalization moves, even if they appear detrimental to their well-being (Brickley et al., 1988; Ramaswamy et al., 2002). Such internationalization moves may significantly increase costs without offering commensurate benefits. All the above effects of domestic financial institutional ownership allow costs to overshadow benefits at the lower levels of internationalization, resulting in a negative moderating effect on the internationalizationperformance relationship.

However, the negative consequences of a high degree of domestic financial institutional ownership on the internationalization-performance relationship may begin to wane as the standard benefits of economies of scale and scope, risk reduction, and access to strategic assets (Contractor, 2012) start to kick in at higher levels of internationalization. Furthermore, only after the business group has achieved higher levels of internationalization would it be able to exploit its government linkages, to boost the advantages it already enjoys from economies of scale and scope. For example, some of the large acquisition bids from emerging economies such as that by Tata Steel of U.K.'s Corus or Hindalco's (an Aditya Birla group company) acquisition of US-Canadian giant Novelis was being driven by nationalist considerations (Hope, Thomas, \& Vyas, 2011). In such situations, the business 
groups may leverage linkages with government institutions for financing international operations and negotiating with foreign governments. At a more general level, as business groups reach higher levels of internationalization, they become showcases of success stories of native firms in the global arena. In such situations, government through their nominees in the board helps business groups' internationalization by providing critical resources necessary at that higher level of internationalization.

Hypothesis 3a: Domestic financial institutional ownership, in Indian business groups, has a negative moderating effect at lower levels of internationalization.

Hypothesis 3b: Domestic financial institutional ownership, in Indian business groups, has a positive moderating effect at higher levels of internationalization.

Degree of foreign corporate ownership. Foreign investors also have shares in Indian business groups. Douma et al. (2006) report that foreign corporate ownership stakes in Indian business groups are larger and less fragmented than those held by foreign institutional investors, such that they are better aligned to perform active monitoring. Foreign corporate ownership involves joint ventures (JV) or technology collaborations with developed economy firms, primarily to exploit local markets. The local firm enters such an alliance to gain the resources and capabilities of the foreign partner, including equity, technology transfers, foreign directors, consultancy and marketing arrangements, and managerial resource sharing (Douma et al., 2006). With such resources and capabilities, the local firm learns more about international markets and may leverage this knowledge in linkages with other international firms (Mathews, 2006), such that it can avoid common pitfalls and reduce the costs of internationalization.

As business groups are deeply embedded in the institutional setting of their home country and so when they venture abroad, their home country advantages may appear less 
attractive to host country firms (Ramamurti, 2009; Pedersen \& Stucchi , 2014), but the resource capabilities they have acquired through JVs should facilitate their internationalization efforts (Lamin, 2013; Luo \& Tung, 2007). Foreign partners may help them identify investment opportunities abroad, raise foreign capital in road shows in relevant countries, or participate in activities that add to the group's knowledge of overseas business environments and regulatory practices. These benefits are useful for keeping the initial costs arising due to liabilities of foreignness and newness in check. Furthermore, a higher degree of foreign corporate ownership might help domestic managers identify and understand the nature of the risk involved (Lien, Piesse, Strange, \& Filatotchev, 2005), which is particularly helpful for diverse, family-dominated business groups. For example, the B.K. Modi Group of India increased its degree of foreign ownership by entering into a JV with the Italian telecom firm Olivetti Spa (Lamin, 2013). When Modi's software arm ventured into Italy, it set up a successful operation there, based on its learning from the Italian partner in the JV that it set up in India.

A higher degree of foreign corporate ownership also signals management and corporate governance quality, which should make it easier to raise funds and ease financing constraints in host countries (Hoskission, Johnson \& Moesel, 1994; Wruck, 1989; Young, Peng, Ahlstrom, \& Bruton, 2002). Finally, because foreign partners are involved in group operations, they can effectively monitor the internationalization process. Thus, business groups with a high degree of foreign ownership can enjoy these benefits, even at high levels of internationalization.

Hypothesis 4a: Foreign corporate ownership, in Indian business groups, has a positive moderating effect at lower levels of internationalization.

Hypothesis 4b: Foreign corporate ownership, in Indian business groups, has a positive moderating effect at higher levels of internationalization. 


\section{Methods}

Research setting

The present study was set in India, which serves as the home base for many business groups and thus offers fertile ground for choosing an adequately representative sample of internationalization activities by this organizational form. Most firms in India belong to just one group, which facilitates data aggregation at the group level (Goto, 1982; Strachan, 1976). Furthermore, without any active government participation in business groups, the actions that business groups take are independent, free from responses dictated by external agencies. These attributes of Indian business groups provide a more robust test of our hypotheses.

Sample selection

The sample in the empirical tests came from the Prowess database, which includes all firms listed on India's major stock exchanges, including public sector enterprises and foreign firms. We initially extracted data for firms from all business groups in the Prowess database for 2000-2010. We selected this time period because foreign expansion by Indian business groups was rare prior to 2000 (Delios, Gaur, \& Kamal, 2009; Kumar et al., 2012). Next, we dropped business groups that had sales of less than Rs 60 million $^{1}$ (Berger \& Ofek, 1995) and those with only one firm in the network. For our analysis, we needed information about firms' ownership, but private firms are not required to provide ownership data. Therefore,

\footnotetext{
${ }^{1} 1 \mathrm{USD}=\mathrm{Rs} 65.00$ (approx.)
} 
our sample is comprised of business groups which has been operationalized as the aggregate of listed firms affiliated within the same business group. This creates a measurement bias, especially in the construction of ownership variables, but is unavoidable given data concerns $^{2}$. Ultimately, our sample consisted of 185 business groups. On average, there were about 6 firms in each business group which are spread across 3 two-digit NIC industries. Additionally, business groups in our sample has an average sales of Rs 44518.18 million with an average age of 50.67 years and mean foreign sales to total sales of 14.5 percent.

\section{Variables}

Dependent variable. We use the business group as the unit of analysis, and all the variables refer to this group level. The dependent variable is excess return of assets (ROA), which is the difference between the business group's actual ROA and its imputed ROA, calculated as the ROA if each affiliated firm operated on its own. Calculation of excess ROA entailed the following steps. First, we calculated a business group's ROA as the weighted sum of the ROAs of the affiliated firms, using proportion of firm's total assets to business group's total assets as weights. Second, to calculate the imputed ROA, all listed firms belonging to 185 business groups were assigned to a two-digit NIC code, and we determined the median ROA of every NIC. Third, the business group's imputed ROA was calculated by multiplying the proportion of each affiliated firm's total assets to business group's assets with the corresponding median ROA of its two-digit NIC code, then adding the results for all the affiliated firms. Finally, we deduct the business group's imputed ROA from its actual ROA to get the value of the excess ROA.

\footnotetext{
${ }^{2}$ We discuss this further in our Discussion and Conclusion section as a limitation to our study
} 
Our measure of excess ROA is conceptually similar to the excess value measure proposed by Berger and Ofek (1995), except that it is based on accounting rather than stock market data. The Berger and Ofek (1995) methodology allows for a fine-grained measurement of performance that enables us to capture the premium/discount the groups attract. As business groups are in multiple industries, a simple ROA measure does not capture across industry differences, despite large variation (Campa \& Kedia, 2002; Lang \& Stulz, 1994). Excess ROA, on the other hand, compares the performance of the business group to an imputed value, i.e. if all of its affiliated firms in different industries are operated as stand-alone businesses with industry median performance (Berger \& Ofek, 1995). The difference between a business group's actual ROA to its imputed value provides the gain or loss in performance at the business group level. Business groups have both positive and negative excess ROA. Positive excess value indicates that business groups have a superior performance while a negative excess value indicates a reduction in performance. Excess ROA has a mean of 0.020 and a standard deviation of 0.073 with a maximum of 0.246 and a minimum of -0.206 .

Explanatory variables. We explain the construction of our explanatory business group variables in the following list. Additionally, we provide an Appendix which details the construction of all industry-adjusted variables and ownership variables at the business group level.

a. Ownership categories. We first calculate the firms' assets as a proportion of the total assets of the business group. Then, to calculate business group's family ownership (FAMILY), we multiply this proportion of the total assets of each affiliated firm with the percentage of shares held by the founding family (including both family members and family foundations) and those held by group firms, then adding the results for all 
the listed firms within the business group. Similarly, to calculate domestic financial institutional ownership at the business group level (FINANCIAL), we multiply the proportion of assets of each affiliated firm to the percentage of shares owned by domestic (i.e. Indian) financial institutions and then adding the results for all the listed firms within the business group. Finally, we calculate business group level foreign corporate ownership (FOREIGN) by multiplying the proportion of assets of each affiliated firm to the percentage of shares owned by foreign non-financial corporations and adding the results for all the listed firms within the business group.

b. Industry-weighted foreign sales to total sales (dFSTS). The industry-weighted FSTS is the difference between the business group's FSTS and its imputed value. The business group's FSTS is the weighted sum of the FSTS of the affiliated firms, using proportion of firm's sales to the total sales of the business group as weights. To calculate the imputed value, we use the Prowess database and assign all listed firms to a two-digit NIC code. Then we calculate the median FSTS of every NIC. For the business group's imputed FSTS, we multiply the share of each affiliated firm's sales with the corresponding median FSTS of its two-digit NIC, and then add the results for all affiliated firms.

c. Industry-weighted marketing intensity (dMARKETING). Industry-weighted marketing intensity is the difference between the business group's marketing intensity and its imputed value. The business group's marketing intensity is the weighted sum of the marketing intensity of its affiliated firms, using proportion of firm's sales to the total sales of the business group as weights. To calculate the imputed value, we again use the Prowess database, assign all listed firms to a two-digit NIC code, and determine the median marketing intensity of every NIC. For the business group's 
imputed marketing intensity, we multiply the share of each affiliated firm's sales with the corresponding median marketing intensity of its two-digit NIC, and then add the results for all affiliated firms.

d. Industry-weighted R\&D intensity ( $d R \& D)$. This variable calculation is similar to that for industry-adjusted marketing intensity, where we use R\&D intensity in lieu of marketing intensity.

e. Control-cash flow rights wedge (WEDGE). Business group WEDGE is calculated by multiplying the proportion of assets of the firm to the total assets of the business group with the difference between control rights and cash flow rights of the promoter and then adding the results for all the affiliated firms within the business group. Control rights reflect the sum of equity holdings by promoters and by persons acting in concert (PAC), where PAC are affiliates of holding companies or subsidiary companies (Ayyagari, Dau, \& Spencer, 2015). Cash flow rights equal aggregate equity holdings by promoters.

f. Diversification of the business group (DIVERSIFICATION). Business group diversification is measured using Jacquemin and Berry's (1979) entropy measure.

g. Age of the business group (AGE). This variable equals the number of years since the inception of the oldest firm affiliated to the business group

h. Size of the business group (SIZE). We take the natural log of the group's total sales.

i. Current ratio of the business group (CR). We measure the current assets of all listed firms in the business group, divided by total liabilities.

j. Leverage of the business group (LEVERAGE). The total debt of all listed firms in the business group is divided by its total assets. 


\section{Results}

Table 2 contains the means, standard deviation and correlation matrix for all variables in the model. The variance inflation factors for each variable offer no concerns about multicollinearity.

--Please insert Table 2 about here--

To test the hypotheses, we used a panel design with generalized least square (GLS) estimation for the observations from 2000 to 2010. GLS provide corrections for the presence of autocorrelation and heteroscedasticity in panel data (Wooldridge, 2000). Further, this methodology allows researchers to examine variations among cross-sectional units simultaneously with variations within individual units over time (Hsiao, 1995).

We perform a split sample analysis as the moderating effect of ownership categories on group performance are different at lower and higher levels of internationalization. To split the sample we arranged the groups in ascending order of their internationalization and found out the median value (Qian, Khoury, Peng \& Qian, 2010). Groups whose internationalization were larger than the sample median value were classified as being at higher levels of internationalization while those with internationalization values smaller than the sample median were classified as being at lower levels of internationalization ${ }^{3}$. The results of the analysis are presented in Table 3.

--Please insert Table 3 about here-

Models 1a to $4 \mathrm{a}$ and Models $1 \mathrm{~b}$ to $4 \mathrm{~b}$ of Table 3 present the results at lower and higher levels of internationalization, respectively. Model 1a shows that the co-efficient of internationalization is positive for those business groups whose internationalization is below

\footnotetext{
${ }^{3}$ We have also used the sample mean of internationalization to categorize business groups into lower and higher levels of internationalization. The results are similar though less statistically significant.
} 
sample median $(\beta=0.081, \mathrm{p}=0.000)$, thereby supporting Hypothesis $1 \mathrm{a}$. Model $1 \mathrm{~b}$ shows that the co-efficient of internationalization is negative for those groups whose internationalization is above sample median $(\beta=-0.016, p=0.065)$, thereby supporting Hypothesis $1 \mathrm{~b}$. The results hold even after the introduction of the interaction terms.

Model 2a shows the co-efficient of interaction between family ownership and internationalization to be positive $(\beta=0.004, \mathrm{p}=0.000)$ for groups whose levels of internationalization are below the sample median thereby supporting Hypothesis 2a. Model $2 b$ shows the co-efficient of this interaction to be negative $(\beta=-0.005, p=0.068)$ for groups whose levels of internationalization are above the median ${ }_{s}$ thereby supporting Hypothesis $2 b$. We provide a graphical illustration of our results. Figure 1a shows that at lower levels of internationalization, as internationalization increases, performance also increases. However, increase in family ownership results in a steeper increase in performance. Contrary, Figure $1 \mathrm{~b}$ shows that at higher levels of internationalization, an increase in family ownership results in a steeper decline in performance.

In Model 3a, the co-efficient of interaction term between internationalization and domestic financial institutional ownership is negative $(\beta=-0.035, p=0.000)$ for business groups whose levels of internationalization are below the sample median s thereby supporting Hypothesis 3a. Further in Model 3b, the co-efficient of this interaction is positive $(\beta=0.007$, $\mathrm{p}=0.011$ ) for groups whose levels of internationalization are above the median, thereby supporting Hypothesis $3 \mathrm{~b}$. Figure 2a shows that at lower levels of internationalization, an increase in domestic financial institutional ownership results in the decrease of the slope of the upward sloping line. Similarly, Figure $2 b$ shows that at higher levels of internationalization an increase in domestic financial institutional ownership results in the in the decrease of the slope downward sloping line. 
Finally, we find support for Hypothesis 4a but not for Hypothesis 4b. In Model 4a, the co-efficient of interaction term between internationalization and foreign corporate ownership is positive $(\beta=0.011, p=0.000)$ for groups whose internationalization is below the median level, thereby supporting H4a. Figure 3 shows that at lower levels of internationalization, an increase in foreign corporate ownership results in increase of the slope of the upward sloping line. However, as in Model 4b, the co-efficient of interaction between internationalization and foreign corporate ownership is not significant at higher levels of internationalization; we don't find support for Hypothesis 4b. To sum up, our split sample analysis finds support for all the hypotheses, except Hypothesis 4b.

--Please insert Figures 1a to 3 about here-

Among the control variables, industry-adjusted $R \& D$ and marketing intensity have a positive effect on business group performance at lower and higher levels of internationalization respectively. Business groups tend to be risk averse and avoid investing in risky strategies, such as research in new products especially at higher levels of internationalization. However, if a group has already a higher level of internationalization, a higher marketing expenditure would help in increasing its profitability. The control-cash flow rights wedge has a negative effect at lower levels of internationalization but is insignificant at higher levels. Higher wedge results in tunneling of resources to firms that are more central within the business group, thereby reducing performance (Bertrand et al., 2002). However, as business groups internationalize more, stringent corporate governance regulations, particularly in developed markets, makes it difficult for business groups to follow such value reducing mechanisms. Also, diversification exerts negative impacts on business group performance, contrary with some existing studies in institutional voids literature (e.g., Khanna \& Palpeu, 1997). Perhaps by the time of our study (2000-2010), sufficient open 
market institutions had developed in India, which might limit the usefulness of business groups as tools to address market failures at institutional or organizational levels (Chittoor, Kale, Puranam , 2015). Size has a positive effect; larger groups can better absorb the operational and commercial risks that accompany most international ventures (Fiegenbaum et al., 1997; George \& Kabir, 2012). Similarly, older business groups have large repertoires of experience and learning that they can exploit to improve their performance (Majumder, 1997). Finally, the solvency of business groups is another important influence on business group performance. The negative significance of leverage and positive significance of current ratio suggest that poorly performing business groups have high debt, as well as high current liabilities in their balance sheets (Kakani, 2000).

Robustness tests

We have split our sample into higher and lower levels of internationalization based on the sample median value. To test the robustness of such a split and also our results, we examine our hypotheses on the full sample of 185 business groups. Combining Hypotheses 1a and $1 \mathrm{~b}$, we predict an inverted $\mathrm{U}$-shaped relationship between internationalization and performance for Indian business groups. Hypothesis 1a corresponds to the positive side of the inverted U shaped curve where up to a certain level, internationalization increases performance. However, beyond that point, the negative side of the curve takes over where further internationalization decreases performance, which corresponds to Hypothesis 1b. To test the inverted $\mathrm{U}$ shaped relationship, we introduce a quadratic term of internationalization in our regression model besides the linear term.

Hypotheses $2 \mathrm{a}$ to $4 \mathrm{~b}$ examines the moderating effects of ownership categories at different levels of internationalization. Combing Hypotheses $2 a$ with $2 b$, $3 a$ with $3 b$ and $4 a$ 
with $4 \mathrm{~b}$, we predict different moderating effects of ownership categories on the inverted $\mathrm{U}$ shaped relationship. Combining, Hypotheses $2 \mathrm{a}$ and $2 \mathrm{~b}$, at lower levels of internationalization (i.e. the positive side of the inverted $U$ shaped curve), a positive moderating effect of family ownership implies that the positive slope of the curve would be further enhanced; while at higher levels of internationalization (i.e. the negative side of the inverted $U$ shaped curve), a negative moderating effect of family ownership implies that the negative slope of the curve would also be enhanced. Similarly, combining Hypotheses 3a and 3b, at lower levels of internationalization, a negative moderating effect of domestic financial institutional ownership implies that the positive slope of the curve would be reduced; while at higher levels of internationalization, a positive moderating effect of domestic financial institutional ownership implies that the negative slope of the curve would also be reduced. Finally, combining Hypotheses $4 \mathrm{a}$ and $4 \mathrm{~b}$, at lower levels of internationalization, a positive moderating effect of foreign corporate ownership enhances the positive slope. In contrast, at higher levels of internationalization, a positive moderating effect of foreign corporate ownership reduces the negative slope. To test these moderating effects, we interact the different ownership categories with the linear and quadratic terms of internationalization. Table 4 presents these results with full sample.

--Please insert Table 4 about here--

In Table 4, the results from the baseline regression Model 1 (without interaction) reveal a positive, significant coefficient of internationalization $(\beta=0.012, p=0.084)$ and a negative coefficient for its squared term $(\beta=-0.043, p=0.000)$, indicating an inverted Ushaped relationship with performance, in line with Hypotheses $1 \mathrm{a}$ and $1 \mathrm{~b}^{4}$.

\footnotetext{
${ }^{4}$ To test the validity of our inverted $\mathrm{U}$ shaped relationship, we obtained the turning (maximum) point of our curve. Since all our models in Table 4 have both the linear and quadratic term, we use the most complete model (Model 8). We find that the maximum occurs when our value of internationalization is 0.035 , which is very close to the mean (0.038, Table 2), thus validating our relationship (Meyer, 2009).
} 
In Model 2, the coefficient of the interaction term between internationalization and family ownership is positive $(\beta=0.004, p=0.000)$. At lower levels of internationalization, family ownership positively moderates the internationalization-performance relationship, thereby supporting Hypothesis 2a. When we incorporate all the ownership categories in the same model, the co-efficient of the interaction term between the squared term of internationalization and family ownership is negative and significant (Model $8, \beta=-0.421, p$ $=0.001)$, thereby finding that family ownership negatively moderates the internationalization-performance relationship at higher levels of internationalization, supporting Hypothesis $2 b^{5}$.

In Model 4, the coefficient of internationalization and domestic financial institutional ownership is negative $(\beta=-0.036, p=0.000)$, so at lower levels of internationalization, domestic financial institutions negatively moderate the internationalization-performance relationship, thereby supporting Hypothesis 3a. At higher levels, domestic financial institutions positively moderate this relationship (Model 5; $\beta=0.033, p=0.000$ ), supporting Hypothesis $3 b$.

Finally, Model 6 reveals a positive interaction between foreign corporate ownership and internationalization $(\beta=0.011, p=0.000)$, supporting Hypothesis $4 \mathrm{a}$. Model 7 indicates a negative interaction term between the squared term of internationalization and foreign corporate ownership $(\beta=-0.018, p=0.012)$, thus rejecting Hypothesis $4 \mathrm{bWe}$, therefore, find support for Hypothesis $4 \mathrm{a}$ but not for $4 \mathrm{~b}$. To sum up, our robustness results, like our main results, find support for all our Hypothesis, except 4b.

\section{Discussion and conclusion}

\footnotetext{
${ }^{5}$ Model 3 also incorporates the interaction of the squared term of internationalization with family ownership. The co-efficient though negative is insignificant.
} 
This article highlights the impact of group heterogeneity in ownership on the performance implications of international expansion by Indian business groups. We examine both the main effect of internationalization on group performance and the moderating effects of the degree of different types of owners. A noteworthy feature of our study is that we examine both internationalization and performance at the group level, while most previous studies infer group-level effects using firm-level data (Carney et al., 2011). As business groups are networked organizations with coordinated strategic actions (Khanna \& Rivkin, 2001), decisions regarding major strategic endeavors such as internationalization are likely to be taken at the group level rather than at the firm level (Kumar et al., 2012). Academic evidence of this is very limited as previous studies have primarily looked at internationalization at affiliate level rather than at group level (Chittoor et al., 2009; Gaur \& Kumar, 2009; Hundley \& Jacobsen, 1998; Chang, 1995; Elango \& Pattnaik, 2007; Lamin, 2013). However, anecdotal evidence supports otherwise. For example, Ratan Tata, during his tenure as Chairman of the Tata Group, one of India's most respected business groups, has transformed a portfolio of companies into a more focused competitive and unified group, actively internationalizing their operations. While group companies pursued growth according to their strategic needs, the group center played an important role in determining the process and extant of internationalization. For example, Tata Consultancy Service (TCS), the group's information technology company, was allowed to internationalize at a much faster pace by opening subsidiaries in America, Europe, Australia, China and Japan; but Indian Hotels Company, the group's hospitality business, internationalized at a much slower pace and that too through management contracts with small equity positions rather than outright ownership. The group center also influenced the product-market entry decision (Khanna, Palepu, \& 
Bullock, 2009). When Tata Tea wanted to acquire Eight O’ Clock Coffee to enter the U.S. coffee market, it was 'persuaded' by the group center not to do so as it would conflict with the internationalization of Tata Coffee. The critical role that the group center plays is even more evident in the case of Samsung's globalization efforts. Samsung had a phenomenal transformation from a low-cost original equipment manufacturer to a company with one of the most valuable brands in the world. Samsung, like Tata, are highly diversified with business interests in electronics, financial services, information technology, machinery, shipbuilding, and chemicals. When faced with globalization pressures in the 1990s, Lee KunHee who was Chairman of the Samsung group decided to focus on digital technology and aggressively pushed Samsung Electronics to global markets with less emphasis on the other group companies. In fact, the Global Strategy Group at Samsung was known as the “Chairman's project” and was generously funded even during the Asian financial crises when Samsung experienced significant losses (Khanna, Song, \& Lee, 2011).

We find that group internationalization has a different effect on group performance, depending on the level of internationalization. Group profitability increases at lower levels of internationalization, while it decreases at higher level of internationalization. This baseline finding seems to be contradictory to the findings with studies at the affiliate firm level that show that the internationalization - performance relationship is negative at lower levels while it is positive at higher levels of internationalization (see for example, Contractor et al.,2007; Gaur \& Kumar, 2009; ). We argue that the difference in finding is primarily because previous studies have examined internationalization and performance at the firm level, while we examine them at the group level.

Business groups have a powerful ability to pool resources and leverage their larger size to reduce the costs associated with liabilities of foreignness and newness, while 
benefitting from economies of scale and scope. However, as they continue to internationalize further, the advantages of such group effects start to dissipate (Gaur \& Kumar, 2009; Kumar et al., 2012). As business groups fill institutional voids and replace inefficient external markets in their emerging economies (Khanna \& Rivkin, 2001), they become more embedded in the institutional environment of their home market. But filling up of institutional voids may not be effective in international operations, particularly at higher levels of internationalization when the groups enter relatively more developed institutional markets (Gaur \& Kumar, 2009). Further, most business groups are widely diversified in their home market with presence in a wide range of industries (Khanna \& Palepu, 1997). This diversified structure makes the control and coordination of increasing international operations more costly. Operating in multiple industries and countries lead business groups to overstretch their resources; resulting in suboptimal decisions and reduced performance (Kumar et al., 2012). The diminishing group advantages and heightened coordination and control costs at higher levels of internationalization lead to lower profitability as Indian business groups expand into too many international markets.

We also explore how ownership heterogeneity across business groups could influence internationalization and profitability relationship. Our findings offer evidence that home country-specific conditions can modify general models of this relationship, which highlights the importance of contextualizing research. In particular, our findings confirm the varying impacts of different degree of ownership groups, across lower and higher levels of internationalization, challenging the assumptions of owner homogeneity in prior studies (Hill \& Snell, 1989; Januszewski, Köke \& Winter, 2002; Köke \& Renneboog, 2005).

Specifically, we find that as business groups increase their internationalization from lower to higher levels, the moderating effect of degree of family ownership and foreign 
corporate ownership changes from positive to negative; while the moderating effect of degree of domestic financial institutional ownership changes from a negative to positive. Our findings are consistent with our hypotheses, except at higher levels of internationalization we find that the degree of foreign corporate ownership has a negative or an insignificant moderating effect while we predicted a positive moderating effect. We surmise that the representatives of the foreign corporate owners carry out the mandates as set by their home corporate headquarters. Foreign investors' interest in Indian business group firms are primarily driven by their desire to take advantage of the availability of low-cost, trained manpower and exploitation of the large market size (Kumar \& Aggarwal, 2005). To succeed at higher levels of internationalization, business groups need 'competence creation' while foreign investors are more interested in 'competence exploitation' (Cantwell \& Mudambi, $2005 ; 2011)$. This difference in the interest of the foreign investors and the requirement of the business group leads to inferior or no effect on business group performance.

Our results here demonstrate that an explicit incorporation of the context, in terms of the stage of internationalization, is critical in exploring the true effect of ownership. As such, it is important not only to incorporate home country specific conditions (emerging versus developed), but also venture specific conditions (lower versus higher stage of internationalization) to accurately understand the role of moderating factors in the internationalization-performance relationship. Also, the different relationship for business groups compared to that for firms points to the possibility of business groups' international strategy being markedly different from that of individual firms. There is, thus, the need to reinvestigate various facets of international strategy such as choice of foreign market, entry mode, headquarter-subsidiary relationship, knowledge transfer at business group level rather than at the individual firm level. 
For managers, our study demonstrates that business groups experience a positive performance effect from internationalization, but with continued international expansion, they suffer a decline in performance. A high degree of family ownership and foreign corporate ownership has advantages — but only at lower levels of internationalization. Business group owners and managers should explore ways to dilute family ownership as the business group increases their internationalization. Also the degree of foreign corporate ownership in the form of JVs or strategic alliances is less likely to help as business groups reach advanced stage of internationalization. Managers should also restrict the involvement of domestic financial institutions, especially at lower levels of internationalization, because ownership by these entities harms the internationalization-performance relationship. However, when business groups aspire for higher levels of internationalization, managers should exploit the government linkages, through their domestic financial institutional ownership, for financing international operations and negotiating with foreign governments.

Although these findings have important implications both for research and practice, as we have noted above, they also reflect some limitations. First, we confine this study to an investigation of the extent of international diversification, without examining the details of such diversification. Considering the location (developed/developing) and mode of internationalization (acquisitions/greenfield) could provide additional insights. Second, ownership data are available only for publicly listed firms, so we were forced to exclude private and unlisted firms from our study. This has implications on aggregating data from affiliate firm level to group level variables. With some firms being excluded from our analysis of group level variables, we are unable to capture the group level dynamics to the full extent. Future studies should collect data from all firms that are part of a business group to calculate group level variables. Third, the current study only scratches the surface with 
regard to heterogeneity, examining the ownership dimension of business groups. Our findings show that the identity of the owner matters; different types of owners have different impact on the costs and benefits of internationalization for business groups. The net moderating effect of different ownership categories would depend on the owners' resources and relative power in the business groups. For example, UAE based Eithad Airways has a 24 percent equity in Jet Airways, an Indian business group firm. Jet Airways wanted to tap Eithad's international operations to compete in the global airline market while Eithad wanted Jet to focus on the growing domestic market. However, as Jet's financial condition was far from being stable, it was ultimately forced to sell three of its slots at London Heathrow airport to Eithad for USD 70 million (The Indian Express , 2014), thereby renewing its focus on the domestic market. As such, analyzing the net moderating effect of different factors could potentially lead to interesting finding, another direction to extend our study. Besides, studies on other dimensions of heterogeneity — such as power inequities among group members, board of directors' interlocks, and so forth—could continue to unravel how business group heterogeneities influence the internationalization-performance relationship. Finally, future studies could include different types of firms such as state-owned, foreign multinationals and unaffiliated firms and examine the effect of their heterogeneity on the internationalization performance relationship.

To conclude, our results reveal the internationalization - performance relationship at the group level and how this relationship is moderated by business group ownership categories. Our results also demonstrate how the moderating effects by business group owner category vary over lower and higher stages of internationalization. These findings highlight the contingent contribution of owners in the strategy-performance relationship. 
Acknowledgement: We would like to thank the special issue editors Bersant Hobdari, Jing Li, Klaus Meyer, Peter Gammeltoft and two anonymous reviewers for their feedback as well as Mick Carney for final guidance on this manuscript. 


\section{References}

Aguilera, R.V., \& Jackson, G. 2003. The cross-national diversity of corporate governance: Dimensions and determinants. Academy of Management Review, 28(3): 447-465

Allen J.W., \& Phillips G.M. 2000. Corporate equity ownership, strategic alliances and product market relationships. Journal of Finance 55(6): 2791-2815.

Anderson, R. C. \&. Reeb, D. M 2003. Founding family ownership and firm performance: Evidence from S\&P 500. Journal of Finance, 58(3):1301-1328.

Ayyagari, M, Dau, L.F., \& Spencer, J. 2015. Strategic responses to FDI in emerging markets: Are core members more responsive than peripheral members of business groups? Academy of Management Journal, 58(6):1869-1894

Baek, J.S., Kang, J. K., \& Lee, I. 2006. Business groups and tunneling: Evidence from private securities offerings by Korean chaebols. Journal of Finance, 61(5): 2415-2449.

Barkema, H. G., Bell, J. H. J., \& Pennings, J. M. 1996. Foreign entry, cultural barriers, and learning. Strategic Management Journal, 17(2): 151-166.

Barkema, H. G., \& Vermeulen, F. 1998. International expansion through start-up or acquisition: A learning perspective. Academy of Management Journal, 41(1): 7-26.

Bausch, A., \& Krist, M. 2007. The effect of context-related moderators on the internationalization-performance relationship: Evidence from meta-analysis. Management International Review 47(3): 319-347.

Berger, P.G. \& Ofek, E. 1995. Diversification's effect on firm value. Journal of Financial Economics, 37(1): 39-65.

Bertrand, M., Mehta, P., \& Mullainathan, S. 2002. Ferreting out tunneling: An application to Indian business groups, Quarterly Journal of Economics, 117 (1): 121-148.

Bhaumik, S. K., Driffield. N., \& Pal S. 2010. Does ownership structure of emerging-market firms affect their outward FDI? The case of the Indian automotive and pharmaceutical sectors. Journal of International Business Studies, 41(3):437-450

Brickley, J. A., Lease R. C., \& Smith Jr. C. W.1988. Ownership structure and voting on antitakeover amendments. Journal of Financial Economics, 20 (January-March): 267-291

Campa, J.M., \& Kedia, S. 2002. Explaining the diversification discount. Journal of Finance 57(4): 1731-1762.

Cantwell, J., \& Mudambi, R. 2005. MNE competence-creating subsidiary mandates. Strategic Management Journal, 26(12): 1109-1128.

Cantwell, J., \& Mudambi, R. 2011. Physical attraction and the geography of knowledge sourcing in multinational enterprises. Global Strategy Journal, 1(3-4): 206-232.

Carney, M. 2004. The institutions of industrial restructuring in Southeast Asia. Asia Pacific Journal of Management, 21 (1/2): 171-188.

Carney, M., Gedajlovic, E.R., Heugens, P.P.M.A.R., Essen, M.V., \& Oosterhout, J.V. 2011. Business group affiliation, performance, context and strategy: A meta-analysis. Academy of Management Journal, 54 (3): 437-460.

Caves, R. E. 1971. International corporations: The industrial economics of foreign investment. Economica, 38(Feb): 1-27.

Casson, M. 1999. The economics of the family firm. Scandinavian Economic History Review, 47(1):10-23 
Chacar, A., \& Vissa B. 2005. Are emerging economies less efficient? Performance persistence and the impact of business group affiliation. Strategic Management Journal, 26 (10): 933-946.

Chami, R. 1999. What's different about family businesses? University of Notre Dame Working Paper. Notre Dame: University of Notre Dame.

Chang, S. J. 1995. International expansion strategy of Japanese firms: Capability building through sequential entry. Academy of Management Journal, 38 (2): 383-407.

Chang S., Chung C., \& Mahmood, I. P. 2006. When and how does business group affiliation promote firm innovation? A tale of two emerging economies. Organization Science, 17 (5): $637-656$

Chang, S.J., \& Hong, J. 2000. Economic performance of group-affiliated companies in Korea; Intra-group resource sharing and internal business transaction. Academy of Management Journal, 43 (3): 429-448.

Chang, S. J., \& Rhee, J.H.. 2011. Rapid FDI expansion and firm performance. Journal of International Business Studies, 42(8): 979-994.

Chao, M., \& Kumar, V. 2010. The impact of institutional distance on the international diversity-performance relationship. Journal of World Business, 45(1): 93-103.

Chen, G., Chittoor, R., \& Vissa, B. 2015. Modernizing without westernizing: Social structure and economic action in the Indian financial sector. Academy of Management Journal, 58(2): 511-537.

Chen, V.Z., Li, J., Shapiro, D.M., \& Zhang, X. 2014. Ownership structure and innovation: An emerging market perspective. Asia Pacific Journal of Management, 31(1): 1-24.

Chittoor, R., \& Ray, S. 2007. Internationalization paths of Indian pharmaceutical firms-A strategic group analysis. Journal of International Management, 13(3): 338-355

Chittoor, R., Kale, P., Puranam, P. 2015. Business groups in developing capital markets: Towards a complementary perspective. Strategic Management Journal, 36(9): 12771296.

Chittoor, R., Sarkar M.B., Ray S., \& Aulakh P.S. 2009. Third--world copycats to emerging multinationals: Institutional changes and organizational transformation in the Indian pharmaceutical industry. Organization Science 20 (1): 187-205.

Claessens, S., Djankov, S., \& Lang, L. H. P. 2000. East Asian corporations: Heroes or villains? Discussion paper 409, World Bank, Washington, DC.

Clavier E., Rienda L., \& Quer D. 2009. Family firms' international commitment: The influence of family-related factors. Family Business Review, 22 (2): 125-135.

Contractor, F. 2012. Why do multinational firms exist? A theory note about the effect of multinational expansion on performance and recent methodological critiques. Global Strategy Journal, 2(4): 318-331.

Contractor F.J., Kumar V., \& Kundu, S. K. 2007. Nature of the relationship between international expansion and performance: The case of emerging market firms. Journal of World Business, 42(4): 401-417

Contractor, F.J., Kundu, S. \& Hsu, C-C. 2003. A three-stage theory of international expansion: The link between multinationality and performance in the service sector. Journal of International Business Studies 34(1): 5-18.

Cuervo-Cazurra, A. 2012. How the analysis of developing country multinational companies helps advance theory: Solving the Goldilocks debate. Global Strategy Journal, 2 (3): 153-167. 
Daily, C. M., \& Dollinger M. J. 1993. Alternative methods for identifying family vs. nonfamily managed small businesses. Journal of Small Business Management, 31 (2):79-90.

Delios, A., Gaur, A. S., \& Kamal, S. 2009. International acquisitions and the globalization of firms from India. In Chaisse, J., \& Gugler, P. (Eds.), Expansion of trade and FDI in Asia: Strategic and policy challenges, Routledge: New York.

Dieleman, M., \& Sachs, W. M. 2008. Co-evolution of institutions and corporations in emerging economies: How the Salim group morphed into an institution of Suharto's crony regime. Journal of Management Studies, 45 (7): 1274-1300.

Douma, S. George, R., \& Kabir R. 2006. Foreign and domestic ownership, business groups, and firm performance: Evidence from a large emerging market. Strategic Management Journal, 27 (7): 637-657

Economic Times, The 2014. The Mukesh Ambani's twin kids Isha \& Akash made directors of Reliance Jio Infocomm \& Reliance Retail Ventures, Oct 12.

Elango, B., \& Pattnaik, C. 2007. Building capabilities for international operations through networks: A study of Indian firms. Journal of International Business Studies, 38 (4): 541-555.

Fernández, A., \& Nieto, M. J. 2006. Impact of ownership on the international involvement of SMEs. Journal of International Business Studies, 37 (3), 340-351.

Fiegenbaum, A., Shaver, J. M., \& Yeung, B. 1997. Which firms expand to the Middle East: The experience of U.S. multinationals. Strategic Management Journal, 18 (2): 141148.

Filatotchev, I., Lien, Y.C., \& Piesse, J. 2005. Corporate governance and performance in publicly listed, family-controlled firms: Evidence from Taiwan. Asia Pacific Journal of Management 22 (3): 257-283.

Gallo, M. A., \& Sveen, J. 1991. Internationalizing the family business: Facilitating and restraining factors. Family Business Review, 4 (2): 181-190.

Gaur, A.S., \& Delios, A. 2015. International diversification of emerging market firms: The role of ownership structure and group affiliation. Management International Review, 55(2): 235-253.

Gaur, A. S., \& Kumar V. 2009. International diversification, business group affiliation and firm performance: Empirical evidence from India. British Journal of Management, 20 (2): $172-186$

George, R., \& Kabir, R. 2012. Heterogeneity in business groups and the corporate diversification-firm performance relationship. Journal of Business Research, 65 (3): 412-420.

Ghemawat, P., \& Khanna, T. 1998. The nature of diversified business groups: A research design and two case studies. Journal of Industrial Economics, 46 (1): 35-61.

Goto, A. 1982. Business groups in a market economy. European Economic Review, 19 (1), 53-70.

Gubbi, S.R., Aulakh, P.S., \& Ray, S. 2015. International search behavior of business group affiliated firms: Scope of institutional changes and intragroup heterogeneity. Organization Science, 26(5): 1485-1501.

Guillén, M.F. 2000. Business groups in emerging economies: A resource based view. Academy of Management Journal, 43 (3): 362-380.

Guillén, M., \& Garcia-Canal E. 2012. Emerging markets rule: Growth strategies of the new global giants .McGraw Hill. 
Habbershon, T. J., \& Williams, M. L. 1999. A resource-based framework for assessing the strategic advantages of family firms. Family Business Review, 12 (1): 1-22.

Hennart, J.F. 2007. The theoretical rationale for a multinationality-performance relationship. Management International Review, 47(3):423-452.

Hill, C.W.L., \& Snell, S.A. 1989. Effects of ownership structure and control on corporate productivity. Academy of Management Journal 32 (1): 25-46.

Hitt, M.A., Connelly B., Tihanyi L., \& Certo, T. 2010. Marching to the beat of different drummers: The influence of institutional owners on competitive actions. Academy of Management Journal, 53(4): 723-742

Hsiao, C. 2003. Analysis of panel data. Cambridge University Press. Cambridge, U.K.

Hope, O., Thomas, W., \& Vyas, D. 2011. The cost of pride: Why do firms from developing countries bid higher? Journal of International Business Studies, 42, 128-151.

Hoskisson, R. E., Johnson, R. A., \& Moesel, D. D. 1994. Corporate divestiture intensity in restructuring firms - effects of governance, strategy, and performance. Academy of Management Journal, 37 (5): 1207-1251.

Hundley G., \& Jacobson C. K. 1998. The effects of the keiretsu on the export performance of Japanese companies: Help or hindrance? Strategic Management Journal 19 (10): 927-937.

Hymer, S. H. 1976. A study of direct foreign investment. Cambridge, MA: MIT Press.

Jacquemin, A.P., \& Berry C.H. 1979. Entropy measure of diversification and corporate growth. Journal of Industrial Economics, 27(4): 359-369

Januszewski S.I., Köke J., \& Winter J.K. 2002. Product market competition, corporate governance and firm performance: An empirical analysis for Germany. Research in Economics, 56 (3): 299-332.

Johnson, R. A., Schnatterly, K., Johnson, S. A. \& Chiu, S. C. 2010. Institutional investors and institutional environment: A comparative analysis and review. Journal of Management Studies, 47 (8):1590-613

Kakani, R.K. 2000. Financial performance and diversification strategy of Indian business groups. Doctoral dissertation, Indian Institute of Management, Calcutta

Khanna, T., \& Palepu, K. 1997. Why focused strategies may be wrong for emerging markets. Harvard Business Review, 75(4), 41-51.

Khanna, T., \& Palepu, K. 2000. Is group affiliation profitable in emerging markets: An analysis of Indian diversified business groups. Journal of Finance, 55 (2): 867-891.

Khanna, T., Palepu, K. \& Bullock, R. 2009. House of Tata: Acquiring a global footprint. Harvard Business School Case, 9-708-446

Khanna, T., \& Rivkin, J.W. 2001. Estimating the performance effects of business groups in emerging markets. Strategic Management Journal, 22 (1): 45-74.

Khanna, T, Song, J., \& Lee, K. 2011. The globe: The paradox of Samsung's rise. Harvard Business Review, 89(7/8): 142-147.

Khanna, T., \& Yafeh Y.2007. Business groups in emerging markets: Paragons or parasites? Journal of Economic Literature, 45 (2): 331-372.

Kim, H., Kim, H., \& Lee, P. M. 2008. Ownership strategy and the relationship between financial slack and R\&D investments: Evidence from Korean firms. Organizational Science, 19(3): 404-418.

Kim, W.C., Hwang, P., \& Burgers, W.P.1993. Multinationals' diversification and the riskreturn trade-off. Strategic Management Journal, 14 (4): 275-286. 
Kirca, A.H., Roth, K., Hult, G.T.M., \& Cavusgil, S.T. 2012. The role of context in the multinationality-performance relationship: A meta-analytic review. Global Strategy Journal, 2: 108-121.

Kogut, B. 1985. Designing global strategies: Comparative and competitive value added chains. Sloan Management Review, 27(Fall): 27-38.

Kogut, B., \& Chang, S. J. 1991. Technological capabilities and Japanese foreign direct investment in the United States. Review of Economics and Statistics, 73(3): 401-413.

Köke J., \& Renneboog L. 2005. Do corporate control and product market competition lead to stronger productivity growth? Evidence from market-oriented and blockholder-based governance regimes. Journal of Law and Economics 48 (2): 475-516.

Kumar, N., \& Aggarwal A. 2005. Liberalization, outward orientation and in-house R\&D activity of multinational and local firms: A quantitative exploration for Indian manufacturing. Research Policy, 34(4): 441-460.

Kumar, V., Gaur, A. S., \& Pattnaik, C. 2012. Product diversification and international expansion of business groups: Evidence from India. Management International Review, 52 (2): 175-92

Kumar, V., Mudambi, R., \& Gray, S. 2013. Internationalization, innovation and institutions: The 3 I's underpinning the competitiveness of emerging market firms. Journal of International Management, 19(3): 203-206.

Lamin, A. 2013. The business group as an information resource: An investigation of business group affiliation in the Indian software services industry. Academy of Management Journal, 56 (5):1487-1509

Lang, L. H. P. \& Stulz, R. M. 1994.Tobin's q, corporate diversification, and firm performance. Journal of Political Economy, 102(6):1248-1280.

Leff, N.H. 1978. Industrial organization and entrepreneurship in the developing countries: The economic groups. Economic Development and Cultural Change, 26(4): 661-675.

Li, L. 2007. Multinationality and performance: A synthetic review and research agenda. International Journal of Management Reviews 9(2): 117-139.

Lictenthaler, U. 2009. Absorptive capacity, environmental turbulence, and the complementarity of organizational learning processes. Academy of Management Journal, 52(4): 822-846.

Lien, Y.C., Piesse, J., Strange, R., \& Filatotchev, I. 2005. The role of corporate governance in FDI decisions: Evidence from Taiwan. International Business Review, 14 (6): 739 763.

Lu, J., \& Beamish, P. 2001. The internationalization and performance of SMEs. Strategic Management Journal, 22(6-7): 565-586.

Lu, J., \& Beamish, P. 2004. International diversification and firm performance: The S-Curve hypothesis. Academy of Management Journal, 47(4): 598-609.

Luo, Y., \& Tung, R. 2007. International expansion of emerging market enterprises: A springboard perspective. Journal of International Business Studies, 38 (4): 481-498.

Mackie, J. 1992. Changing patterns of big business in Southeast Asia. In McVey R. (Ed.), Southeast Asian capitalism. Ithaca, NY: Cornell University Southeast Asia Program, 161-190.

Majocchi A., \& Strange R. 2012. International diversification: The impact of ownership structure, the market for corporate control and board independence. Management International Review, 52 (6): 879-900.

Majumder, S. 1997. The Impact of size and age on firm-level performance: Some evidences from India. Review of Industrial Organization, 12(2): 231-241. 
Manikandan, K.S., \& Ramachandran, J.2015. Beyond institutional voids: Business groups incomplete markets, and organizational form. Strategic Management Journal, 36(4):598-617

Mathews, J. A. 2006. Dragon multinationals: New players in 21st century of globalization. Asia

Pacific Journal of Management, 23 (1): 5-27.

Meyer, K.E. 2009. Motivating, testing, and publishing curvilinear effects in management research, Asia Pacific Journal of Management, 26(2): 187-193.

Monks, R., \& Minow, N. 1995. Corporate governance. Cambridge, MA: Blackwell Business.

Morck, R., Wolfenzon, D., \& Yeung, B. 2005. Corporate governance, economic entrenchment, and growth. Journal of Economic Literature, 43 (3): 655-720.

Nachum, L. 2000. Economic geography and the location of TNCs: Financial and professional service FDI to the USA. Journal of International Business Studies, 31(3): 367-385.

Nieto, M. J. 2001. Tipos de propiedad y comportamiento estratégico de la empresa. Unpublished Ph.D. dissertation, Departamento de Economía de la Empresa, Universidad Carlos III de Madrid, Spain.

Oh, C.H. \& Contractor, F.J. 2012. The role of territorial coverage and product diversification in the multinationality-performance relationship. Global Strategy Journal, 2:122136.

Oh, C.H. \& Contractor, F.J. 2014. A regional perspective on multinational expansion strategies: reconsidering the three-stage paradigm. British Journal of Management, 25(S1): S42-S59.

Pedersen, T., \& Stucchi, T. 2014. Business groups, institutional transition, and the internationalization of firms from emerging economies. In A. Cuervo-Cazurra \& R. Ramamurti (Eds.), Understanding Multinationals from Emerging Markets. Cambridge Univ Press, Cambridge.

Poza, E. J., Alfred, T., \& Maheshwari, A. 1997. Stakeholder perceptions of culture and management practices in family and family firms: A preliminary report. Family Business Review, 10 (2): 135-155.

Qian, G., Khoury, T. A., Peng, M. W. and Qian, Z. 2010. The performance implications of intra- and inter-regional geographic diversification. Strategic Management Journal, 31(9):1018-1030.

Ramamurti, R. 2000. A multilevel model of privatization in emerging economies. Academy of Management Review, 25(3): 525-550.

Ramamurti, R. 2009. What have we learned about EMNEs? In Ramamurti R. \&. Singh J. V (Eds.), Emerging multinationals from emerging markets. Cambridge: Cambridge University Press.

Ramamurti R., \& Singh J. V. 2009. Emerging multinationals from emerging markets, Chapter 2. Cambridge, UK: Cambridge University Press.

Ramaswamy, K., Li, M., \& Petitt, B.2012. Why do business groups matter? A study of market failure and performance among Indian manufacturers. Asia Pacific Journal of Management, 29(3)643-658.

Ramaswamy, K., Li, M., \& Veliyath, R. 2002. Variations in ownership behavior and propensity to diversify: A study of the Indian corporate context. Strategic Management Journal, 23 (4): 345-358. 
Rugman, A.M., \& Oh, C.H. 2010. Does the regional nature of multinationals affect the multinationality and performance relationship? International Business Review, 19(5): 479-488.

Ruigrok, W., \& Wagner, H. 2003. Internationalization and performance: An organizational learning perspective. Management International Review, 9(2): 63-83.

Singh, D.A., \& Gaur, A.S. 2013 Governance structure, innovation and internationalization: Evidence from India. Journal of International Management, 19 (3): 300-309

Strachan, H. 1976. Family and other business groups in economic development: The case of Nicaragua. New York: Praeger.

Tan, D., \& Meyer, K. E. 2010. Business groups' outward FDI: A managerial resources perspective. Journal of International Management, 16(2): 154-164

The Economist. 2011. The 2011 oil shock: More of a threat to the world economy than investors seem to think. http://www.economist.com/node/18281774, March $3^{\text {rd }}$.

The Indian Express. 2014. Jet Airways, Etihad Airways deal rocked by fresh trouble, http://indianexpress.com/article/business/companies/jet-airways-etihad-airways-dealrocked-by-fresh-trouble/\#sthash.92ySHbCD.dpuf, June 19.

Thomas, D.E., \& Eden, L. 2004. What is the shape of the multinationality-performance relationship? Multinational Business Review, 12(1): 89-110.

Tihanyi, L., Johnson, R.A., Hoskission, R.E., \& Hitt, M.A. 2003. Institutional ownership differences and international diversification: The effects of boards of directors and technological opportunity. Academy of Management Journal, 46(2): 195-211.

Verbeke, A., \& Forootan, M.Z. 2012. How good are multinationality-performance (M-P) empirical studies? Global Strategy Journal 2(4): 332-344.

Verbeke, A., Li, L., \& Goerzen, A. 2009. Toward more effective research on the multinationality-performance relationship. Management International Review 49(2): 149-162.

Wan, W. P., \& Hoskisson, R. 2003. Home country environments, corporate diversification strategies, and firm performance. Academy of Management Journal, 46(1):27-45.

Ward, J. 1988. The special role of strategic planning for family businesses. Family Business Review, 1 (2): 105-117.

Wooldridge, J.M. 2000. Introductory econometrics: A modern approach. Cengage Learning Custom Publishing

Wruck K. H. 1989. Equity ownership concentration and firm value: Evidence from private equity financings. Journal of Financial Economics, 23 (1):3-28.

Yaprak, A., \& Karademir, B. 2010. The internationalization of emerging market business groups: An integrated literature review. International Marketing Review, 27(2): 245262

Yiu, D. 2011. Multinational advantages of Chinese business groups: A theoretical exploration. Management and Organization Review. 7(2): 249-277.

Yoshihara, K. 1988. The rise of ersatz capitalism in south-east Asia. Oxford: Oxford University Press.

Young, M., Peng, M., Ahlstrom, D., \& Bruton, G.D. 2002. Governing the corporation in emerging economies: A principal principal perspective. Academy of Management Proceedings, E: 1-6.

Zaheer, S. 1995. Overcoming the liability of foreignness. Academy of Management Journal 38(2): 341-363.

Zahra, S. A. 2003. Entrepreneurial risk taking in family firms. Family Business Review, 18 (1): $23-40$. 
Zattoni, A., Pedersen, T., \& Kumar, V. 2009. The performance of group-affiliated firms during institutional transition: A longitudinal study of Indian firms. Corporate Governance: An International Review 17(4): 510-523. 
Table 1. STUDIES OF MODERATING EFFECTS IN THE INTERNATIONALIZATION-PERFORMANCE RELATIONSHIP

\begin{tabular}{|c|c|c|c|c|}
\hline Study & Sample & Main effects & Moderating Effects & Conclusion \\
\hline $\begin{array}{l}\text { Chang \& } \\
\text { Rhee } \\
\text { (2011) }\end{array}$ & $\begin{array}{l}276 \text { publicly } \\
\text { listed Korean } \\
\text { firms in the } \\
\text { manufacturin } \\
\text { g sector, } \\
\text { 1970-2003 }\end{array}$ & $\begin{array}{l}\text { Linear } \\
\text { internationalization } \\
\text { - performance } \\
\text { relationship }\end{array}$ & $\begin{array}{l}\text { R\&D intensity, } \\
\text { advertising intensity, } \\
\text { leverage, industry } \\
\text { globalization }\end{array}$ & $\begin{array}{l}\text { Advertising intensity and industry } \\
\text { globalization positively moderate } \\
\text { the speed of internationalization - } \\
\text { performance relationship; leverage } \\
\text { negatively moderates it; R\&D } \\
\text { intensity has no effect. }\end{array}$ \\
\hline $\begin{array}{l}\text { Chao \& } \\
\text { Kumar } \\
\text { (2009) }\end{array}$ & $\begin{array}{l}500 \text { firms } \\
\text { from } 31 \\
\text { countries, } \\
2002-2004\end{array}$ & $\begin{array}{l}\text { Quadratic } \\
\text { internationalization } \\
\text {-performance } \\
\text { relationship }\end{array}$ & $\begin{array}{l}\text { Regulative \& } \\
\text { normative distances } \\
\text { between home and } \\
\text { host countries }\end{array}$ & $\begin{array}{l}\text { Regulative distance negatively } \\
\text { moderates, and normative distance } \\
\text { positively moderates the } \\
\text { internationalization -performance } \\
\text { relationship }\end{array}$ \\
\hline $\begin{array}{l}\text { Gaur \& } \\
\text { Kumar } \\
\text { (2009) }\end{array}$ & $\begin{array}{l}240 \text { Indian } \\
\text { firms, 1997- } \\
2001\end{array}$ & $\begin{array}{l}\text { Quadratic } \\
\text { internationalization } \\
\text {-performance } \\
\text { relationship }\end{array}$ & Group affiliation & $\begin{array}{l}\text { Group affiliation negatively } \\
\text { moderates the relationship of } \\
\text { internationalization and } \\
\text { performance }\end{array}$ \\
\hline $\begin{array}{l}\text { Kirca et al. } \\
\text { (2012) }\end{array}$ & $\begin{array}{l}\text { Meta- } \\
\text { analysis of } \\
141 \text { studies }\end{array}$ & & $\begin{array}{l}\text { Firm size, type of firm } \\
\text { multinationality, } \\
\text { industry effects, } \\
\text { country effects, stage } \\
\text { of firm } \\
\text { internationalization }\end{array}$ & $\begin{array}{l}\text { Industry and country effects } \\
\text { positively moderate; type of firm } \\
\text { multinationality negatively } \\
\text { moderates; firm size and stage of } \\
\text { firm internationalization have no } \\
\text { effects on internationalization - } \\
\text { performance relationship }\end{array}$ \\
\hline $\begin{array}{l}\text { Oh \& } \\
\text { Contractor } \\
\text { (2012) }\end{array}$ & $\begin{array}{l}1,162 \text { U.S. } \\
\text { firms, } 1998- \\
2004\end{array}$ & $\begin{array}{l}\text { Linear } \\
\text { internationalization } \\
\text {-performance } \\
\text { relationship }\end{array}$ & Product diversification & $\begin{array}{l}\text { Product diversification negatively } \\
\text { moderates the relationship of } \\
\text { internationalization and } \\
\text { performance for firms expanding } \\
\text { into a region proximate to home } \\
\text { country but positively moderates it } \\
\text { for firms expanding into distant } \\
\text { regions }\end{array}$ \\
\hline $\begin{array}{l}\text { Oh \& } \\
\text { Contractor } \\
\text { (2014) }\end{array}$ & $\begin{array}{l}315 \text { U.S. } \\
\text { firms, } 1998- \\
2004\end{array}$ & $\begin{array}{l}\text { Cubic } \\
\text { internationalization } \\
\text { - performance } \\
\text { relationship }\end{array}$ & Product diversification & $\begin{array}{l}\text { Product diversification negatively } \\
\text { moderates the internationalization } \\
\text {-performance relationship }\end{array}$ \\
\hline $\begin{array}{l}\text { Rugman \& } \\
\text { Oh (2010) }\end{array}$ & $\begin{array}{l}\text { World's 500 } \\
\text { largest firms, } \\
2001-2005\end{array}$ & $\begin{array}{l}\text { Linear } \\
\text { internationalization } \\
\text {-performance } \\
\text { relationship }\end{array}$ & $\begin{array}{l}\text { R\&D intensity, } \\
\text { advertising intensity }\end{array}$ & $\begin{array}{l}\text { R\&D intensity negatively } \\
\text { moderates, advertising intensity } \\
\text { positively moderates, the } \\
\text { internationalization - performance } \\
\text { relationship }\end{array}$ \\
\hline $\begin{array}{l}\text { Verbeke et } \\
\text { al. (2009) }\end{array}$ & Theoretical & & $\begin{array}{l}\text { Variety of strategic } \\
\text { motivations for } \\
\text { foreign direct } \\
\text { investment, } \\
\text { environmental } \\
\text { complexity, } \\
\text { organizational } \\
\text { complexity }\end{array}$ & $\begin{array}{l}\text { All variables moderate the } \\
\text { internationalization - performance } \\
\text { relationship, though directionality } \\
\text { is difficult to predict }\end{array}$ \\
\hline
\end{tabular}


Table 2 Means, standard deviations and correlations

\begin{tabular}{|c|c|c|c|c|c|c|c|c|c|c|c|c|c|c|c|}
\hline Variables & Mean & $\begin{array}{l}\text { Std. } \\
\text { Dev. }\end{array}$ & 1 & 2 & 3 & 4 & 5 & 6 & 7 & 8 & 9 & 10 & 11 & 12 & 13 \\
\hline $\begin{array}{l}\text { 1. Excess } \\
\text { ROA }\end{array}$ & 0.020 & 0.073 & 1 & & & & & & & & & & & & \\
\hline 2. dFSTS & 0.038 & 0.144 & 0.029 & 1 & & & & & & & & & & & \\
\hline 3. $d R \& D$ & 0.002 & 0.006 & $0.061^{* *}$ & $0.100 * *$ & 1 & & & & & & & & & & \\
\hline $\begin{array}{l}4 . \\
\text { dMARKE } \\
\text { TING }\end{array}$ & 0.006 & 0.020 & -0.039 & $0.105^{* *}$ & $0.246^{* *}$ & 1 & & & & & & & & & \\
\hline $\begin{array}{l}5 . \\
\text { FAMILY }\end{array}$ & 22.189 & 22.322 & 0.033 & $-0.047^{*}$ & -0.036 & $-0.078 * *$ & 1 & & & & & & & & \\
\hline $\begin{array}{l}6 . \\
\text { FINANCI }\end{array}$ & 7.421 & 7.362 & 0.023 & $-0.081 * *$ & $0.108^{* *}$ & $0.058^{*}$ & -0.019 & 1 & & & & & & & \\
\hline $\begin{array}{l}7 . \\
\text { FOREIG } \\
\mathrm{N}\end{array}$ & 2.251 & 6.264 & 0.042 & $0.093^{* *}$ & $-0.072 * *$ & 0.033 & -0.015 & $-0.059^{*}$ & 1 & & & & & & \\
\hline $\begin{array}{l}8 . \\
\text { WEDGE }\end{array}$ & 18.454 & 18.683 & 0.022 & -0.041 & -0.014 & -0.044 & $0.896^{* *}$ & 0.041 & -0.027 & 1 & & & & & \\
\hline $\begin{array}{l}9 . \\
\text { DIVERSI } \\
\text { FICATIO } \\
\mathrm{N}\end{array}$ & 0.645 & 0.498 & -0.012 & 0.031 & $-0.058^{*}$ & 0.009 & $-0.067 * *$ & $0.091 * *$ & -0.014 & 0.006 & 1 & & & & \\
\hline 10. AGE & 50.666 & 27.852 & $0.091 * *$ & -0.020 & 0.037 & -0.040 & $0.089^{* *}$ & $0.216^{* *}$ & 0.020 & $0.116^{* *}$ & $0.397 * *$ & 1 & & & \\
\hline 11. SIZE & 9.425 & 1.522 & $0.217^{* * *}$ & 0.036 & $0.076^{* *}$ & -0.036 & $0.204 * *$ & $0.258^{* *}$ & $0.052 *$ & $0.269^{* *}$ & $0.414 * *$ & $0.312 * *$ & 1 & & \\
\hline $\begin{array}{l}\text { 12. CR } \\
13 . \\
\text { LEVERA } \\
\text { GE }\end{array}$ & $\begin{array}{l}2.203 \\
0.422\end{array}$ & $\begin{array}{l}2.312 \\
0.523\end{array}$ & $\begin{array}{l}0.088^{* *} \\
-0.231 * *\end{array}$ & $\begin{array}{l}-0.114^{* *} \\
-0.063 * *\end{array}$ & $\begin{array}{l}0.015 \\
081 * *\end{array}$ & $\begin{array}{l}-0.085^{* *} \\
-0.026\end{array}$ & $\begin{array}{l}0.007 \\
-0.086 * *\end{array}$ & $\begin{array}{l}-0.081 * * \\
-0.010\end{array}$ & $\begin{array}{l}-0.030 \\
-0.049 *\end{array}$ & $\begin{array}{l}-0.018 \\
-0.073 * *\end{array}$ & $\begin{array}{l}-0.104^{* *} \\
-0.015\end{array}$ & $\begin{array}{l}-0.125 * * \\
-0.101 * *\end{array}$ & $\begin{array}{l}-0.013 \\
-0.228 * *\end{array}$ & $\begin{array}{l}1 \\
-0.081^{* *}\end{array}$ & 1 \\
\hline
\end{tabular}


Table 3: Regression results with split sample

\begin{tabular}{|c|c|c|c|c|c|c|c|c|}
\hline \multirow{2}{*}{ Variables } & \multicolumn{4}{|c|}{ Lower levels of internationalization } & \multicolumn{4}{|c|}{ Higher levels of internationalization } \\
\hline & Model 1a & Model 2a & Model 3a & Model 4a & Model 1b & Model 2b & Model 3b & Model 4b \\
\hline \multirow[t]{2}{*}{ CONSTANT } & $-0.083 * * *$ & $-0.082 * * *$ & $-0.078 * * *$ & $-0.082 * * *$ & $-0.040 * * *$ & $-0.039 * * *$ & $-0.040 * * *$ & $-0.040 * * *$ \\
\hline & $(0.011)$ & $(0.011)$ & $(0.011)$ & $(0.011)$ & $(0.012)$ & $(0.011)$ & $(0.012)$ & $(0.012)$ \\
\hline \multirow[t]{2}{*}{ dFSTS } & $0.081 * * *$ & $0.078 * * *$ & $0.083 * * *$ & $0.081 * * *$ & $-0.016 *$ & $-0.006 *$ & $-0.016 *$ & $-0.018 * *$ \\
\hline & $(0.014)$ & $(0.013)$ & $(0.014)$ & $(0.013)$ & $(0.009)$ & $(0.003)$ & $(0.009)$ & $(0.009)$ \\
\hline \multirow[t]{2}{*}{$\mathrm{dR} \& \mathrm{D}$} & 0.324 & $0.374 *$ & $0.445^{*}$ & 0.343 & -0.318 & -0.318 & -0.305 & -0.304 \\
\hline & $(0.229)$ & $(0.227)$ & $(0.227)$ & $(0.224)$ & $(0.246)$ & $(0.250)$ & $(0.247)$ & $(0.244)$ \\
\hline \multirow[t]{2}{*}{ dMARKETING } & 0.053 & 0.046 & 0.050 & 0.051 & $0.104 *$ & $0.097 *$ & $0.099 *$ & $0.104 * *$ \\
\hline & $(0.066)$ & $(0.067)$ & $(0.067)$ & $(0.067)$ & $(0.053)$ & $(0.053)$ & $(0.054)$ & $(0.053)$ \\
\hline \multirow[t]{2}{*}{ FAMILY } & $0.003 * * *$ & $0.003 * * *$ & $0.004 * * *$ & $0.003 * * *$ & 0.000 & -0.000 & 0.000 & 0.000 \\
\hline & $(0.001)$ & $(0.001)$ & $(0.001)$ & $(0.001)$ & $(0.000)$ & $(0.000)$ & $(0.000)$ & $(0.000)$ \\
\hline \multirow[t]{2}{*}{ FINANCIAL } & 0.000 & 0.000 & 0.000 & 0.000 & $0.001 * * *$ & $0.001 * * *$ & $0.001 * * *$ & $0.001 * * *$ \\
\hline & $(0.000)$ & $(0.000)$ & $(0.000)$ & $(0.000)$ & $(0.000)$ & $(0.000)$ & $(0.000)$ & $(0.000)$ \\
\hline \multirow[t]{2}{*}{ FOREIGN } & 0.000 & 0.000 & 0.000 & 0.000 & $0.005 *$ & $0.004 *$ & $0.005^{*}$ & $0.006^{*}$ \\
\hline & $(0.000)$ & $(0.000)$ & $(0.000)$ & $(0.000)$ & $(0.003)$ & $(0.002)$ & $(0.003)$ & $(0.004)$ \\
\hline \multirow[t]{2}{*}{ WEDGE } & $-0.001 * * *$ & $-0.001 * * *$ & $-0.001 * * *$ & $-0.001 * * *$ & -0.000 & -0.000 & -0.000 & -0.000 \\
\hline & $(0.000)$ & $(0.000)$ & $(0.000)$ & $(0.000)$ & $(0.000)$ & $(0.000)$ & $(0.000)$ & $(0.000)$ \\
\hline \multirow[t]{2}{*}{ DIVERSIFICATION } & $-0.026 * * *$ & $-0.025 * * *$ & $-0.026 * * *$ & $-0.026 * * *$ & $-0.010 * * *$ & $-0.010 * * *$ & $-0.010 * * *$ & $-0.010 * * *$ \\
\hline & $(0.003)$ & $(0.003)$ & $(0.003)$ & $(0.003)$ & $(0.003)$ & $(0.003)$ & $(0.003)$ & $(0.003)$ \\
\hline \multirow[t]{2}{*}{ AGE } & $0.002 * * *$ & $0.002 * * *$ & $0.003 * * *$ & $0.003 * * *$ & 0.000 & 0.000 & 0.000 & 0.000 \\
\hline & $(0.000)$ & $(0.000)$ & $(0.000)$ & $(0.000)$ & $(0.000)$ & $(0.000)$ & $(0.000)$ & $(0.000)$ \\
\hline \multirow[t]{2}{*}{ SIZE } & $0.014 * * *$ & $0.014 * * *$ & $0.013 * * *$ & $0.014 * * *$ & $0.011 * * *$ & $0.011 * * *$ & $0.011 * * *$ & $0.011 * * *$ \\
\hline & $(0.001)$ & $(0.001)$ & $(0.001)$ & $(0.001)$ & $(0.001)$ & $(0.001)$ & $(0.001)$ & $(0.001)$ \\
\hline \multirow[t]{2}{*}{$\mathrm{CR}$} & $0.005 * * *$ & $0.005 * * *$ & $0.005 * * *$ & $0.005 * * *$ & $0.011 * * *$ & $0.011 * * *$ & $0.011 * * *$ & $0.011 * * *$ \\
\hline & $(0.001)$ & $(0.001)$ & $(0.001)$ & $(0.001)$ & $(0.001)$ & $(0.001)$ & $(0.001)$ & $(0.001)$ \\
\hline \multirow[t]{2}{*}{ LEVERAGE } & $-0.049 * * *$ & $-0.049 * * *$ & $-0.048 * * *$ & $-0.049 * * *$ & $-0.059 * * *$ & $-0.059 * * *$ & $-0.059 * * *$ & $-0.060 * * *$ \\
\hline & $(0.005)$ & $(0.005)$ & $(0.005)$ & $(0.005)$ & $(0.005)$ & $(0.005)$ & $(0.005)$ & $(0.005)$ \\
\hline \multirow[t]{2}{*}{ dFSTS*FAMILY } & & $0.004 * * *$ & & & & $-0.005^{*}$ & & \\
\hline & & $(0.000)$ & & & & $(0.003)$ & & \\
\hline dFSTS* FINANCIAL & & & $\begin{array}{l}-0.035^{* * *} \\
(0.004)\end{array}$ & & & & $\begin{array}{l}0.007 * * \\
(0.003)\end{array}$ & \\
\hline dFSTS* FOREIGN & & & & $\begin{array}{l}0.011 * * * \\
(0.001)\end{array}$ & & & & $\begin{array}{l}0.008 \\
(0.014)\end{array}$ \\
\hline No. of observations & 950 & 950 & 950 & 950 & 951 & 951 & 951 & 951 \\
\hline Year effects & Included & Included & Included & Included & Included & Included & Included & Included \\
\hline Wald Chi-Square & $754.55 * * *$ & $1044.29 * * *$ & $707.33 * * *$ & $711.49 * * *$ & $500.52 * * *$ & $459.11 * * *$ & $481.82 * * *$ & $451.98 * * *$ \\
\hline
\end{tabular}


Table 4: Regression results with full sample

\begin{tabular}{|c|c|c|c|c|c|c|c|c|}
\hline & Model 1 & Model 2 & Model 3 & Model 4 & Model 5 & Model 6 & Model 7 & Model 8 \\
\hline \multicolumn{9}{|l|}{ Independent variables } \\
\hline \multirow[t]{2}{*}{ Constant } & $-0.049 * * *$ & $-0.048 * * *$ & $-0.049 * * *$ & -0.048 *** & $-0.052 * * *$ & $-0.044 * * *$ & $-0.049 * * *$ & $-0.063 * * *$ \\
\hline & $(0.010)$ & $(0.011)$ & $(0.011)$ & $(0.011)$ & $(0.010)$ & $(0.010)$ & $(0.011)$ & $(0.015)$ \\
\hline \multirow[t]{2}{*}{ dFSTS } & $0.012 *$ & $0.011 *$ & 0.009 & $0.013^{* *}$ & 0.008 & $0.013^{* *}$ & $0.013^{* *}$ & $0.003^{* *}$ \\
\hline & $(0.007)$ & $(0.006)$ & $(0.006)$ & $(.007)$ & $(0.006)$ & $(0.006)$ & $(0.006)$ & $(0.001)$ \\
\hline \multirow[t]{2}{*}{$\mathrm{dFSTS}^{2}$} & $-0.043 * * *$ & $-0.041 * * *$ & $-0.047 * * *$ & $-0.041 * * *$ & $-0.037 * * *$ & $-0.046^{* * * *}$ & $-0.040 * * *$ & $-0.043 * * *$ \\
\hline & $(0.012)$ & $(0.010)$ & $(0.011)$ & $(0.012)$ & $(0.011)$ & $(0.011)$ & $(0.010)$ & $(0.013)$ \\
\hline \multirow[t]{2}{*}{$\mathrm{dR} \& \mathrm{D}$} & 0.102 & 0.150 & 0.196 & 0.147 & 0.164 & 0.080 & 0.121 & 0.208 \\
\hline & $(0.202)$ & $(0.198)$ & $(0.201)$ & $(0.201)$ & $(0.198)$ & $(0.199)$ & $(0.199)$ & $(0.202)$ \\
\hline \multirow{2}{*}{ dMARKETING } & -0.057 & -0.060 & -0.058 & -0.058 & -0.066 & -0.063 & -0.056 & -0.055 \\
\hline & $(0.067)$ & $(0.067)$ & $(0.067)$ & $(0.067)$ & $(0.066)$ & $(0.067)$ & $(0.068)$ & $(0.067)$ \\
\hline \multirow[t]{2}{*}{ FAMILY } & 0.000 & 0.000 & 0.000 & 0.000 & 0.000 & 0.000 & 0.000 & $-0.000^{*}$ \\
\hline & $(0.000)$ & $(0.000)$ & $(0.000)$ & $(0.000)$ & $(0.000)$ & $(0.000)$ & $(0.000)$ & $(0.000)$ \\
\hline \multirow[t]{2}{*}{ FINANCIAL } & $-0.001 * * *$ & $-0.001 * * *$ & $-0.001 * * *$ & $-0.000 * *$ & $-0.001 * * *$ & $-0.001 * * *$ & $-0.001 * * *$ & $-0.003 * *$ \\
\hline & $(0.000)$ & $(0.000)$ & $(0.000)$ & $(0.000)$ & $(0.000)$ & $(0.000)$ & $(0.000)$ & $(0.002)$ \\
\hline \multirow[t]{2}{*}{ FOREIGN } & 0.000 & 0.000 & 0.000 & 0.000 & 0.000 & 0.000 & 0.000 & 0.007 \\
\hline & $(0.000)$ & $(0.000)$ & $(0.000)$ & $(0.000)$ & $(0.000)$ & $(0.000)$ & $(0.000)$ & $(0.007)$ \\
\hline \multirow{2}{*}{ WEDGE } & -0.000 & -0.000 & -0.000 & -0.000 & -0.000 & -0.000 & -0.000 & -0.000 \\
\hline & $(0.000)$ & $(0.000)$ & $(0.000)$ & $(0.000)$ & $(0.000)$ & 0000) & $(.000)$ & $(0.000)$ \\
\hline \multirow[t]{2}{*}{ DIVERSIFICATION } & $-0.016 * * *$ & $-0.016 * * *$ & $-0.016 * * *$ & $-0.016 * * *$ & $-0.015 * * *$ & $-0.016^{* * *}$ & $-0.016 * * *$ & $-0.015 * * *$ \\
\hline & $(0.003)$ & $(0.003)$ & $(0.003)$ & $(0.003)$ & $(0.003)$ & $(0.003)$ & $(0.003)$ & $(0.003)$ \\
\hline \multirow[t]{2}{*}{ AGE } & $0.000 * * *$ & $0.000 * * *$ & $0.000 * * *$ & $0.000 * *$ & $0.000 * * *$ & $0.000 * * *$ & $0.000 * * *$ & $0.000 * * *$ \\
\hline & $(0.000)$ & $(0.000)$ & $(0.000)$ & $(0.000)$ & $(0.000)$ & $(0.000)$ & $(0.000)$ & $(0.000)$ \\
\hline \multirow[t]{2}{*}{ SIZE } & $0.011 * * *$ & $0.011 * * *$ & $0.011 * * *$ & $0.011 * * *$ & $0.012 * * *$ & $0.011 * * *$ & $0.011 * * *$ & $0.011 * * *$ \\
\hline & $(0.001)$ & $(0.001)$ & $(0.001)$ & $(0.001)$ & $(0.001)$ & $(0.001)$ & $(0.001)$ & $(0.001)$ \\
\hline \multirow[t]{2}{*}{ CR } & $0.006 * * *$ & $0.006 * * *$ & $0.006 * * *$ & $0.006 * * *$ & $0.006 * * *$ & $0.006 * * *$ & $0.006 * * *$ & $.006 * * *$ \\
\hline & $(0.001)$ & $(0.001)$ & $(0.001)$ & $(0.001)$ & $(0.001)$ & $(0.001)$ & $(0.001)$ & $(0.001)$ \\
\hline \multirow[t]{2}{*}{ LEVERAGE } & $-0.052 * * *$ & $-0.052 * * *$ & $-0.051 * * *$ & $-0.051 * * *$ & $-0.051 * * *$ & $-0.053 * * *$ & $-0.051 * * *$ & $-0.050 * * *$ \\
\hline & $(0.005)$ & $(0.005)$ & $(0.005)$ & $(0.005)$ & $(0.005)$ & $(0.005)$ & $(0.005)$ & $(0.005)$ \\
\hline dFSTS* & & $0.004 * * *$ & -0.010 & & & & & -0.006 \\
\hline FAMILY & & $(0.000)$ & $(0.008)$ & & & & & $(0.009)$ \\
\hline $\mathrm{dFSTS}^{2} *$ & & & -0.006 & & & & & $-0.421 * * *$ \\
\hline FAMILY & & & $(0.008)$ & & & & & $(0.126)$ \\
\hline dFSTS* & & & & $-0.036 * * *$ & -0.006 & & & -0.003 \\
\hline FINANCIAL & & & & $(0.003)$ & $(0.009)$ & & & $(0.009)$ \\
\hline $\mathrm{dFSTS}^{2 *}$ & & & & & $0.033 * * *$ & & & $1.256^{* *}$ \\
\hline FINANCIAL & & & & & $(0.009)$ & & & $(0.520)$ \\
\hline dFSTS* FOREIGN & & & & & & $0.011 * * *$ & -0.007 & -0.013 \\
\hline & & & & & & $(0.001)$ & $(0.007)$ & $(0.009)$ \\
\hline dFSTS $^{2} *$ FOREIGN & & & & & & & $-0.018 * *$ & $-0.890 * * *$ \\
\hline & & & & & & & $(0.007)$ & $(0.332)$ \\
\hline Year effects & Included & Included & Included & Included & Included & Included & Included & Included \\
\hline Wald chi square & $475.66 * * *$ & $656.09 * * *$ & $651.03 * * *$ & $578.55 * * *$ & $690.68 * * *$ & $555.30 * * *$ & $612.80 * * *$ & $671.32 * * *$ \\
\hline No. of Observations & 1901 & 1901 & 1901 & 1901 & 1901 & 1901 & 1901 & 1901 \\
\hline
\end{tabular}

$* * * \mathrm{p}<0.01, * * \mathrm{p}<0.05, * \mathrm{p}<.0 .10$

The figures in parenthesis refer to standard error 
Figure 1a: Interaction of family ownership at lower levels of internationalization (Model 2a in Table

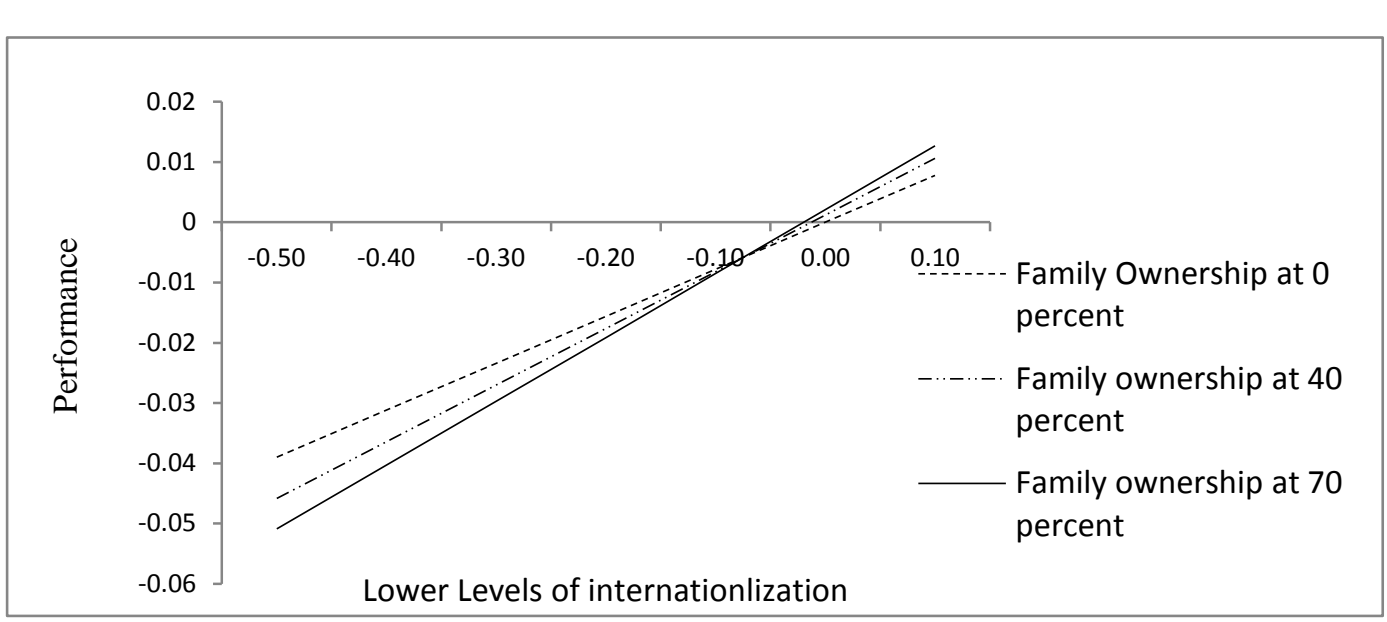

Figure 1b: Interaction of family ownership at higher levels of internationalization (Model $2 \mathrm{~b}$ in Table

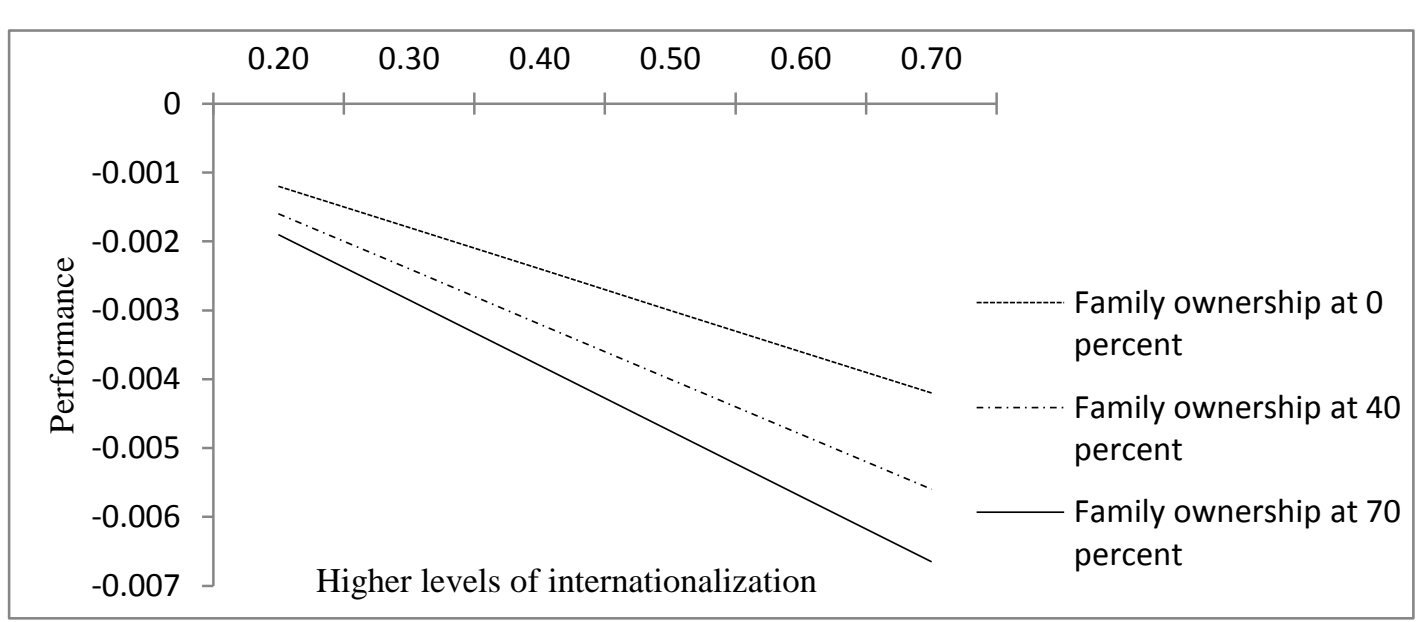


Figure 2a: Interaction of domestic financial institutional ownership (FI) at lower levels of internationalization (Model 3a in Table 3)

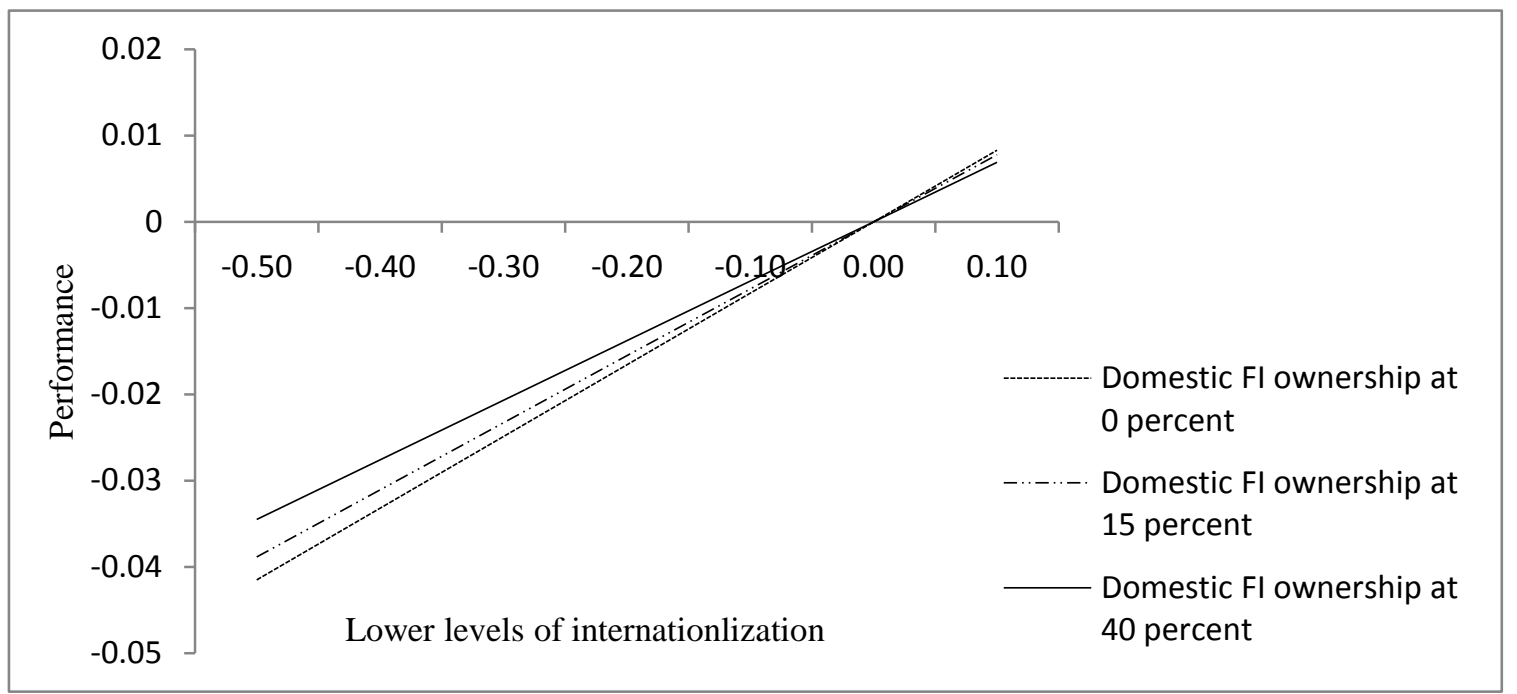

Figure 2b: Interaction of domestic financial institutional (FI) ownership at higher levels of internationalization (Model $3 b$ in Table 3)

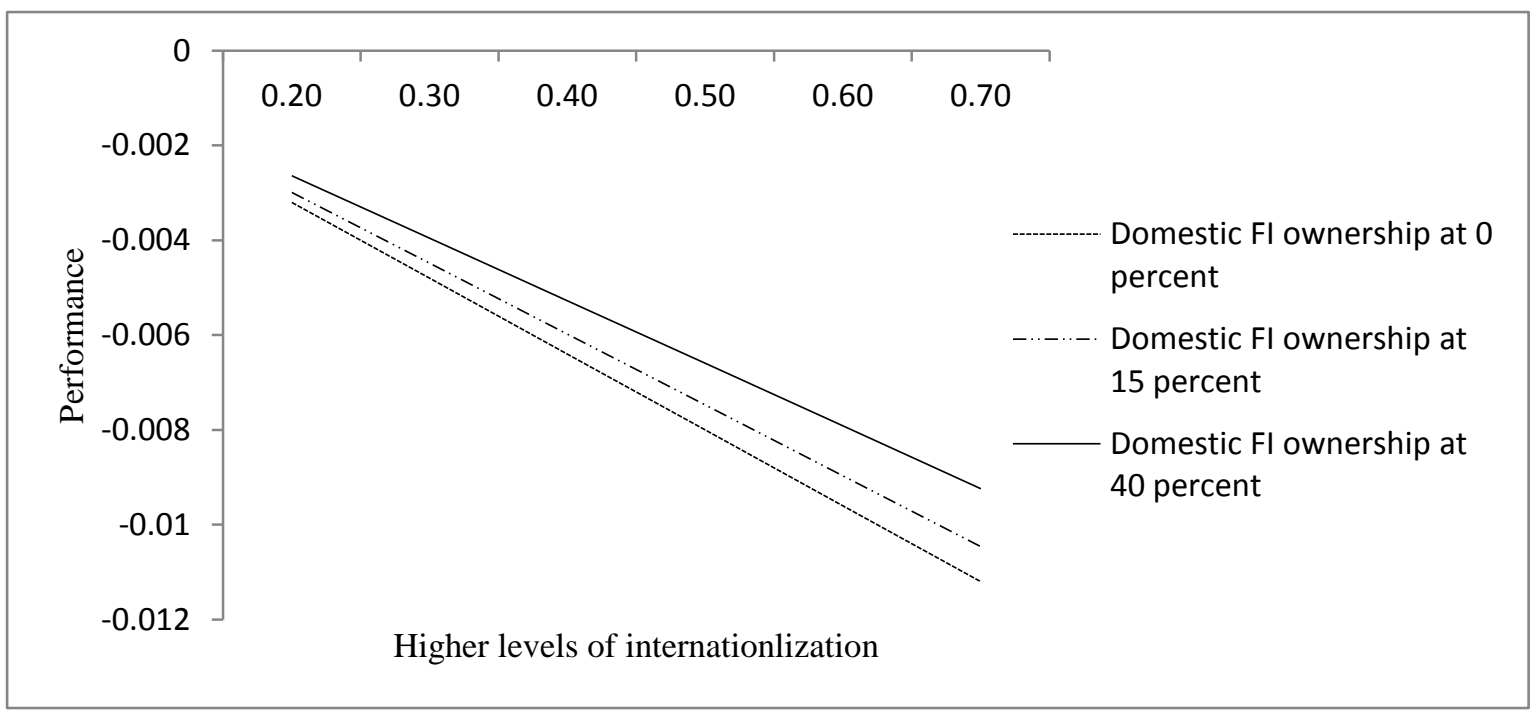


Figure 3: Interaction of foreign corporate ownership at higher levels of internationalization (Model 4a in Table 3)

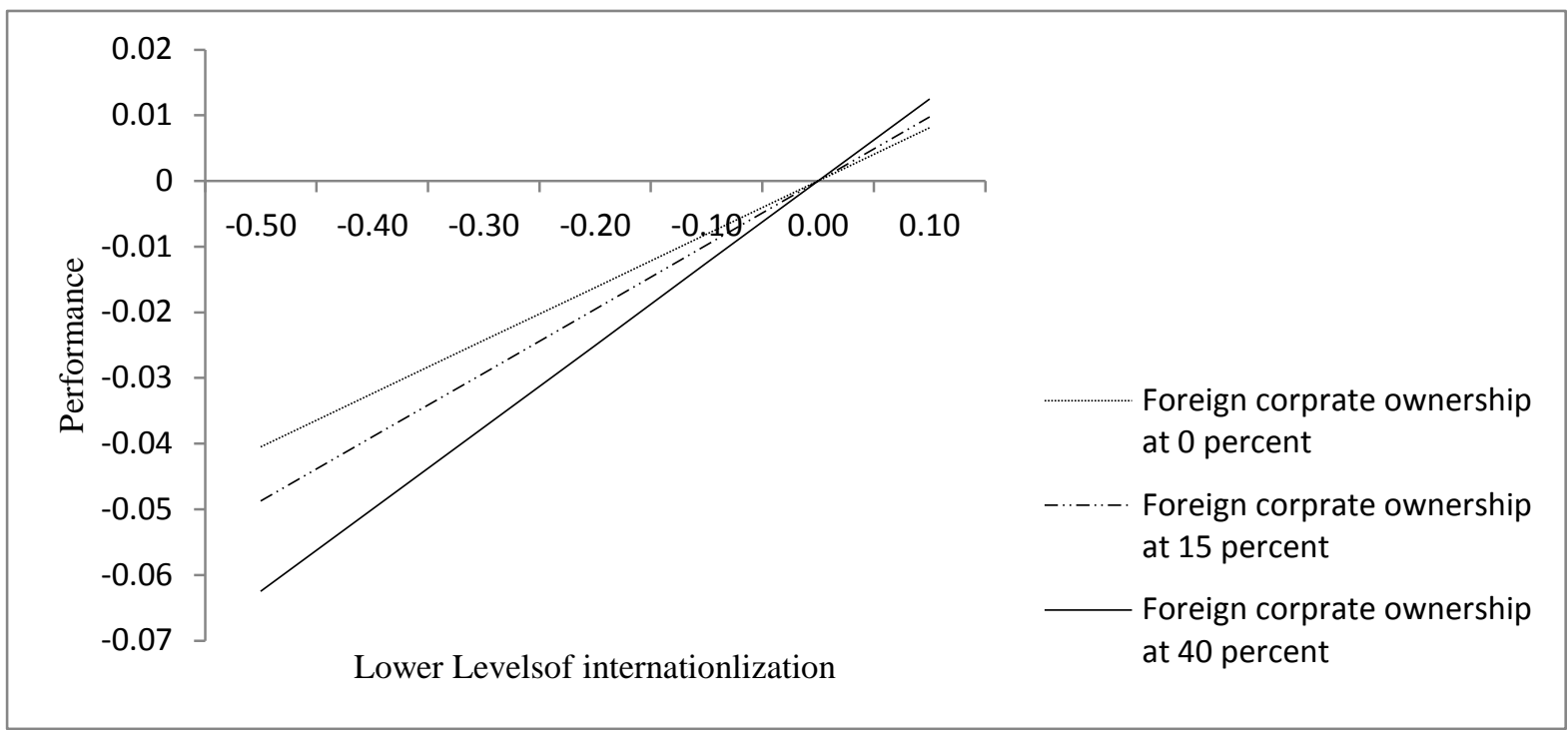


Appendix: Construction of industry-adjusted variables and ownership variables

We consider a business group with $\mathrm{j}$ affiliated listed firms. These $\mathrm{j}$ firms are present in $\mathrm{n}$ twodigit NIC industries. Here, TABG is the sum of the total assets of all listed within the business group, and SBG is the sum of sales of all listed firms within the business group.

a. Excess ROA = ROA of business group - Imputed ROA of the business group

ROA of business group $=\sum_{i=1}^{j} \frac{P B D I T A_{i}}{\text { Assets }_{i}} * \frac{\text { Assets }_{i}}{T_{A B G_{b}}}$ for the $\mathrm{i}^{\text {th }}$ firm within the $\mathrm{b}^{\text {th }}$ business group.

Imputed ROA of the business group $=\sum_{k=1}^{n} \sum_{i=1}^{j} \frac{\text { Assets }_{i}}{T A B G_{b}} * R O A_{k}^{\text {median }}$, where $R O A_{k}^{\text {median }}$ is the median ROA for the $\mathrm{k}^{\text {th }}$ two-digit NIC industry. Firm $\mathrm{i}$ belongs to the $\mathrm{k}^{\text {th }}$ two digit NIC industry.

b. Industry-weighted foreign sales to total sales $=$ FSTS of business group - Imputed FSTS of the business group

FSTS of business group $=\sum_{i=1}^{j} \frac{\text { Foreign sales }_{i}}{\text { Sales }_{i}} * \frac{\text { Sales }_{i}}{S B G_{b}}$ for the $\mathrm{i}^{\text {th }}$ firm within the $\mathrm{b}^{\text {th }}$ business group

Imputed ROA of the business group $=\sum_{k=1}^{n} \sum_{i=1}^{j} \frac{\text { Sales }_{i}}{S B G_{b}} *$ FSTS $_{k}^{\text {median }}$, where FSTS $S_{k}^{\text {median }}$ is the median FSTS for the $\mathrm{k}^{\text {th }}$ two-digit NIC industry

c. Industry-weighted marketing intensity $=$ Marketing intensity of business group - Imputed marketing intensity of the business group

Marketing intensity of business group $=\sum_{i=1}^{j} \frac{\text { Marketing expenditure }_{i}}{\text { Sales }_{i}} * \frac{\text { Sales }_{i}}{S B G_{b}}$ for the $\mathrm{i}^{\text {th }}$ firm within the $b^{\text {th }}$ business group

Imputed marketing intensity of the business group $=\sum_{k=1}^{n} \sum_{i=1}^{j} \frac{\text { Marketing expenditure }_{i}}{S B G_{b}} *$ Marketing intensitykmedian, where Marketing intensitykmedian is the median marketing intensity for the $\mathrm{k}^{\text {th }}$ two-digit NIC industry

d. Control-cash flow rights wedge $=\sum_{i=1}^{j} \frac{\text { Assets }_{i}}{T A B G_{b}} *(\text { Control rights }- \text { Cash flow rights })_{i}$ for the $i^{\text {th }}$ firm within the $b^{\text {th }}$ business group

e. Degree of business group family ownership $=$

$\sum_{i=1}^{j} \frac{A_{\text {ssets }}}{T_{A B G_{b}}} *$ (\% shareholding by founding family and group firms $)_{i}$

f. Degree of business group domestic financial institutional ownership $=\sum_{i=1}^{j} \frac{\text { Assets }_{i}}{\operatorname{TABG}_{b}} *$ (\% shareholding by domestic (i.e. Indian) financial institutions) ${ }_{i}$

g. Degree of business group foreign corporate ownership = $\sum_{i=1}^{j} \frac{A_{\text {ssets }}}{T_{A B G_{b}}} *$ (\% shareholding by foreign non - financial corporations $)_{i}$ 


\section{$\underline{\text { Author Bios }}$}

Saptarshi Purkayastha

Saptarshi is Assistant Professor of Strategy at the Indian Institute of Management, Kolkata. His previous appointment was at the Indian Institute of Management, Kozhikode. He has a $\mathrm{PhD}$ in Management from ICFAI University in 2009. His primary research interest is in investigating the effectiveness of business groups with a focus on internationalization and role of top management. He is member of the Strategic Management Society, Academy of Management and Academy of International Business. His research has been published in International Journal of Management Reviews and Global Business Review.

\section{Vikas Kumar}

Vikas is Associate Professor and Chair of Discipline of International Business at the University of Sydney Business School. His previous appointments were at Bocconi University (2004-09), and as Visiting Scholars at Stanford University (2008-09) and University of Reading (2012-13). He obtained his doctoral degree in International Business in 2004 from Saint Louis University. Vikas's research interests include Internationalization, Emerging Market Firms, Emerging Markets, Business Groups, and Outsourcing/Offshoring. He has been co-guest editor of the special issues in Journal of Management Studies (2010), Journal of International Management (2013), Management International Review (2015). Vikas serves on the Editorial Review Board of JMS, JWB, MIR, TIBR and GSJ. He is the Director of the Emerging Market Internationalization Research Group (EMIRG) at the University of Sydney Business School.

Jane Lu

Jane Lu is James Riady Chair in Asian Business and Economics in the Department of Management and Marketing, the University of Melbourne. Jane Lu received her Ph.D. from the Ivey School of Business, University of Western Ontario in 2001. Her research centers on international strategy such as FDI location choice, entry mode choice and alliance partner selection. Her recent research continues this line of research but with a focus on emerging market firms and their internationalization. Jane Lu has published in leading academic journals such as Academy of Management Journal, Strategic Management Journal, Journal of International Business Studies, Journal of Management and Journal of Business Venturing, among other journals. Jane Lu is a Senior Editor of Asia Pacific Journal of Management and Journal of World Business. 


\section{University Library}

\section{- MINERVA \\ A gateway to Melbourne's research publications}

Minerva Access is the Institutional Repository of The University of Melbourne

Author/s:

Purkayastha, S;Kumar, V;Lu, JW

Title:

Business group heterogeneity and the internationalization-performance relationship: Evidence from Indian business groups

Date:

2017-06-01

Citation:

Purkayastha, S., Kumar, V. \& Lu, J. W. (2017). Business group heterogeneity and the internationalization-performance relationship: Evidence from Indian business groups. ASIA PACIFIC JOURNAL OF MANAGEMENT, 34 (2), pp.247-279. https://doi.org/10.1007/ s10490-016-9489-5.

Persistent Link:

http://hdl.handle.net/11343/283231 